Historic, Archive Document

Do not assume content reflects current scientific knowledge, policies, or practices. 

Indeped Nor.20.19.4.

NEW ROSE KILLARNEY BRILLIANT-THE ACME OF PERFECTION

The most valuable Rose introduced in many years. (For illustration and description, see page 11)

Wholesale Price List-Fall, 1913

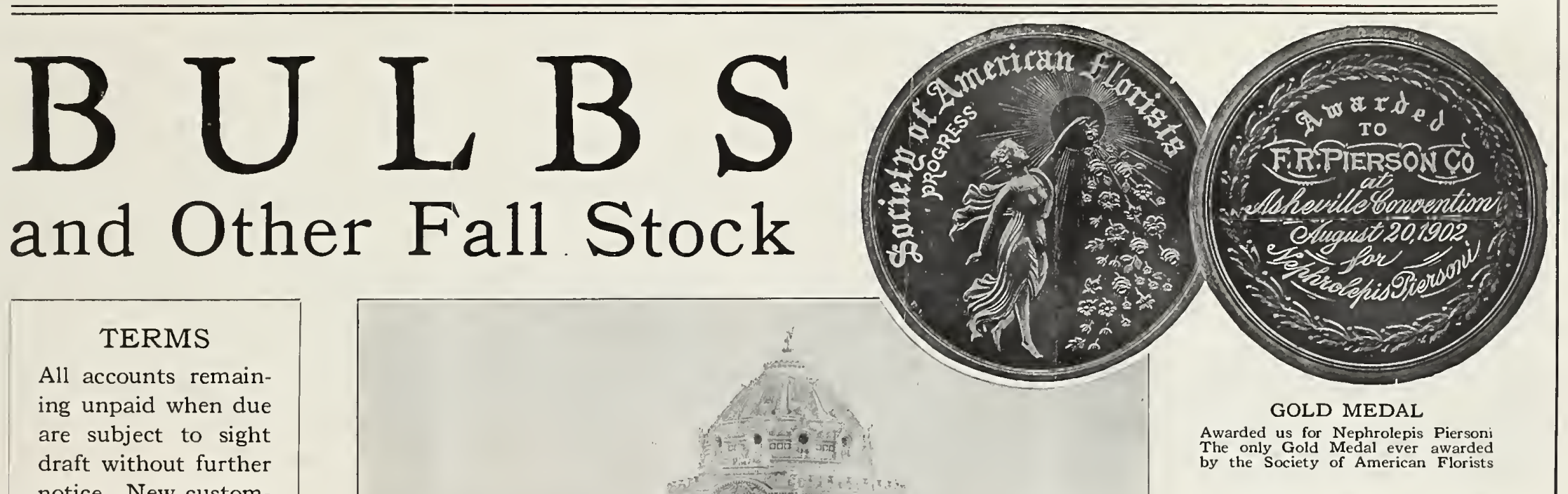
notice. New customers desirous of opening accounts with us must give satisfactory references as to their responsibility. Prices subject to change without notice.

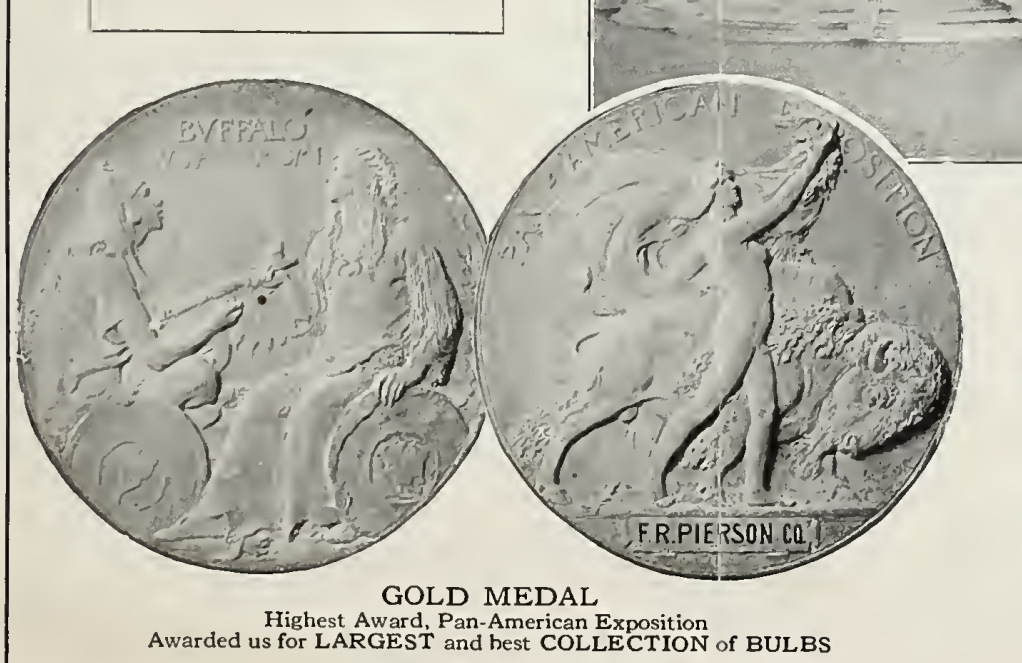

Highest Award, Pan-American Exposition
Awarded us for LARGEST and hest COLLECTION of BULBS

GOLD MEDAL
Louisiana Purchase Exposition, St. Louis
Awarded us for Nephrolepis Piersoni elegantissima

TERMS

To customers of approved credit 60 days' credit will be given, unless otherwise agreed upon, or 3 per cent. discount for cash within 15 days from date of invoice, or 5 per cent. discount where cash is remitted with order.

\section{F. R. PIERSON Co.}

TARRYTOWN-ON-HUDSON, N. Y.

Cable Address: Pierson, Tarrytown (A B C Code used) Long Distance Telephone: Tarrytown, 48 


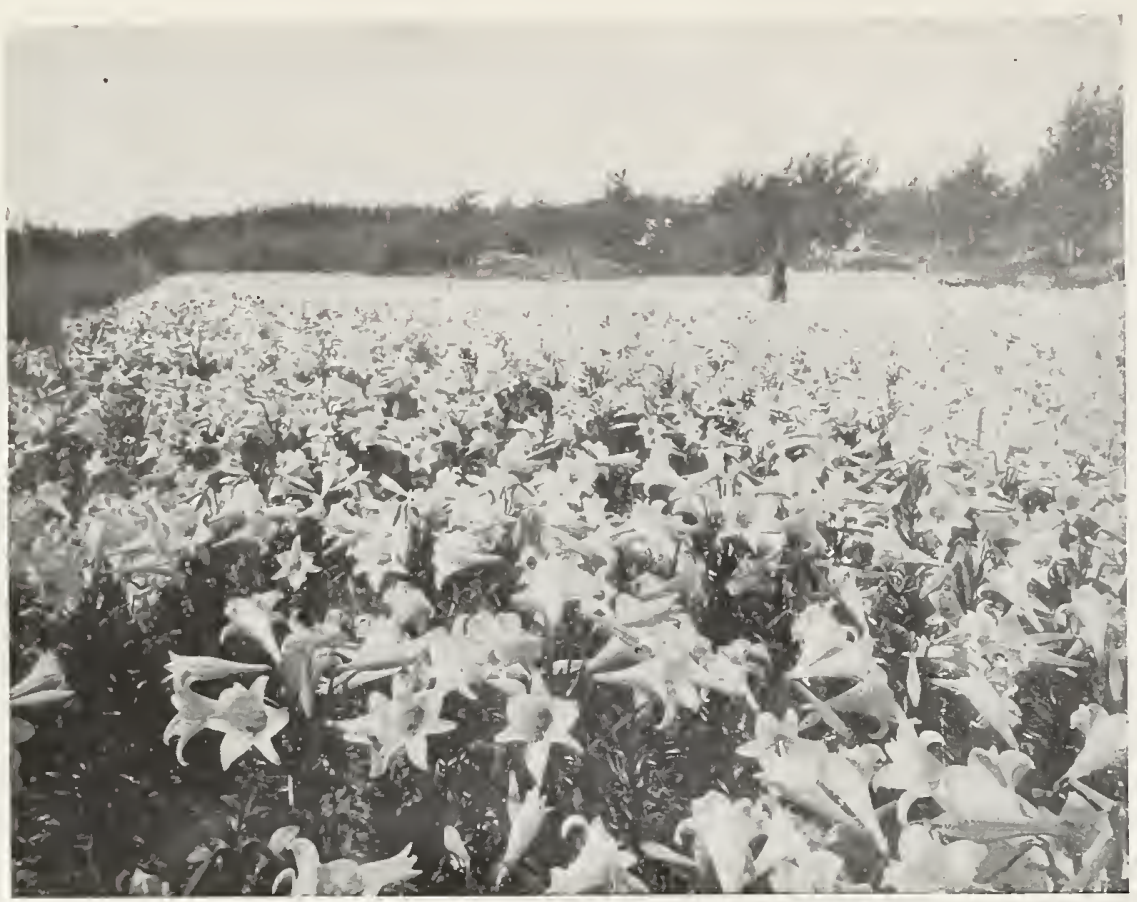

View of One of Our Fields of Lilium llarrisii in Bermuda

\section{LILIUM HARRISII}

(The Bermuda Easter Lily)

\section{Now ready}

We offer a selected stock of the original true Harrisii for early forcing. These bulbs have been grown from the original pure Harrisii, and will be found to be splendid stock for early forcing, for which purpose Harrisii is so valuable. We have had the stock inspected, and are assured that it is almost absolutely pure and almost entirely free from disease. It is not stock picked up indiscriminately from different sources, but is grow from one stock, and will be found very superior to the ordinary Harrisii usually offered, both in regard to freedom from disease, and purity, and is not the late type now so often furnished.

For Christmas flowering, bulbs should be potted as early in August as they can be procured. For thi purpose our 6 to 7 -inch size is preferable, as this size can be brought into bloom much earlier than the larger bulbs. When forced for Christmas, they require a temperature of at least 65 degrees at night.

Not E-We desire to call particular attention to the fact that we do not offer 5 to 7 -inch bulbs as usuall solel, but selected bulbs, measuring 6 to 7 inclies, a much better grade of bulbs than is offered by other house (5) to 7 -inch bulbs, 350 to the case, $\$ 5.50$ per $100, \$ 45.00$ per 1000 7 to 9-inch bulbs, 200 to the case, $\$ 9.00$ per $100, \$ 82.50$ per 1000 (3) to 11-inch bulbs. Sold out.

Full case tots at thousand rates.

\section{LILIUM CANDIDUM}

(The Annunciation Lily) Ready in August

Mammoth bulbs, $\$ 6.00$ per $100, \$ 50.00$ per 1000 .

\section{LILIUM FORMOSUM}

Ready in September

A new, early' ty pe of Lilium Longiflorum, grown on the island of Formosa. Not quite so early as 1 larrisit. but much earlier than the regular Longiflorum. Claimed to be free from disease. Highly recommended $b$, those who have tried it. The bulbs ripen very early, and can be delivered early in September.

7 to 9 -inch bulbs, 250 to the case, $\$ 7.00$ per $100, \$ 60.00$ per 1000 4 to 10 -inch bulbs, 200 to the case, $\$ 10.50$ per $100, \$ 95.00$ per 1000 Fuli case lots at thousand rates.

\section{LILIUM GIGANTEUM}

Ready in October

This flowers much more freely than Multiflorum, and the flowers are larger and longer and have more substance, but it blooms a little later, and requires a little more time to bloom. It is distinguished by its dark brownish stem. It should be grown cool until the buds are set, after which it will stand any amoltnt of forcing.

$$
\begin{aligned}
& 7 \text { to } 9 \text {-inch bulbs, } 300 \text { to the case, } \$ 6.00 \text { per } 100, \$ 52.50 \text { per } 1000 \text {. } \\
& 9 \text { to } 10 \text {-inch bulbs, } 200 \text { to the case, } \$ 11.00 \text { per } 100, \$ 100.00 \text { per } 1000 \text {. } \\
& \text { Full case lots at thousand rates. }
\end{aligned}
$$

\section{LILIUM LONGIFLORUM MULTIFLORUM}

Ready in October

This is a selected type of Longiflorum. It is only a little more expensive than the ordinary Longiflorum. but is more than worth the slight difference in cost, as it blooms much more evenly and flowers mucl more abundantly.

\section{7 to 9 -inch bulbs, 300 to the case, $\$ 6.00$ per $100, \$ 50.00$ per 1000 9 to 10 -inch bulbs, 200 to the case, $\$ 9.50$ per $100, \$ 85.00$ per 1000}

Full case lots at thousand rates.

\section{JAPAN LILIES}

\section{Ready in November}

Auratum. -White, with crimson spots and yellow stripe. $S$ to 9 -inch bulbs, $\$ 6.00$ per $100, \$ 50.00$ per Album. - Pure white. 8 to 9 -inch bulbs, $\$ 10.00$ per $100, \$ 90.00$ per $1000 ; 9$ to 11 -inch bulbs, $\$ 15.00$ Melpomene. - White, very heavily spotted dark crimsol1. $\&$ to 9-inch bulbs, $\$ 6.50$ per $100, \$ 55.00$ Rubrum. White, shaded deep rose and spotted red. S to 9 -inch bulbs, $\$ 6.50$ per $100, \$ 55.00$ per 1000 ;
9 to 11 -inch bulbs, $\$ 10.00$ per $100, \$ 90.00$ per 1000 .

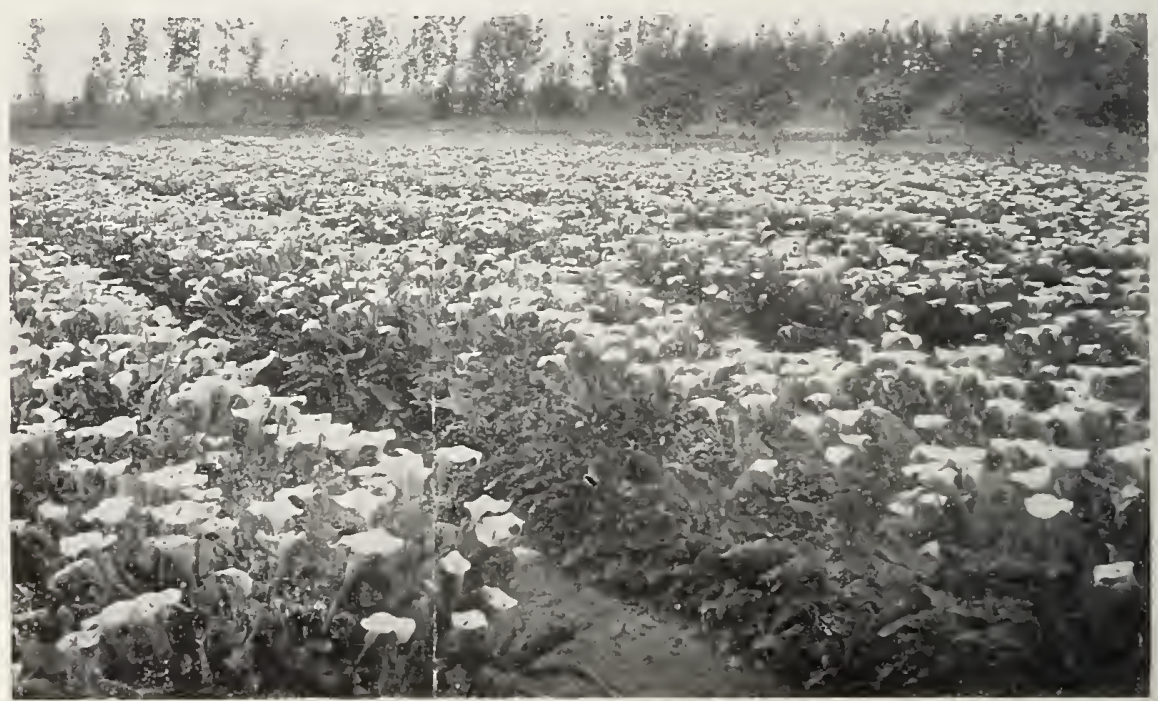

View of One of Our Calla Lily Fields in California 


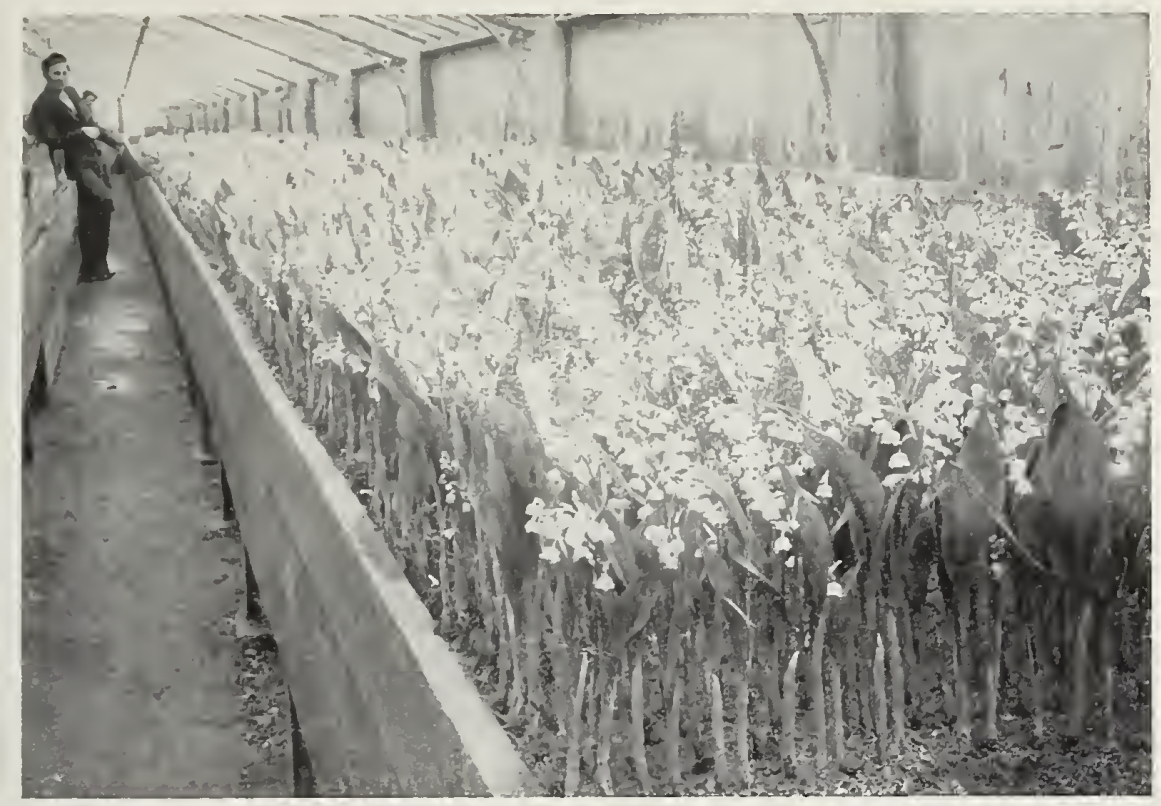

CALLAS

Now ready

Onr bulbs are grown for us by one of the most careful and experienced growers on the Pacific coast They are very carefully cured, and are perfectly sound, with good, strong centers-an important considerattion. Growers will find that these dormant hulbs produce much finer fowers and in greater abundance than plants that have been flowered from year to sear-the
repar's the seeming expense of an outlay for hulhs each year.

$\begin{array}{ll}\text { Selected bulbs, } & 1^{3} 4 \text { inches in diameter, } \$ 10.00 \text { per } \\ \text { Mammoth bulbs, } & 100\end{array}$

\section{CALLA ELLIOTTANA (The Yellow Calla)}

\section{Ready in November}

Flowers large, rich dark golden vellow. Leaves beautifully spotted with white. Valuahle for fall planting in greenlouse for early spring flowering. Both cut flowers and pot plants bring the very highest prices
:It Easter. Bulbs potted in Novemher will, in a night temperature of 5.5 degrees, hloom in about twelve

Extra sized bulbs, $\$ 3.00$ per dozen, $\$ 20.00$ per 100 .

\section{FREESIA REFRACTA ALBA}

Now ready

Very large quantities of these bulbs are now grown for winter-flowering, as they are very useful and prontable,

French-grown.-Mammoth bulbs, $3 / 4$-inch in diameter, $\$ 1.50$ per $100, \$ 10.00$ per 1000 .

Purity.-..Extra sized bulbs, $\$ 2.00$ per $100, \$ 15.00$ per 1000

\section{ASTILBE, OR SPIREA}

Ready in November

Gladstone. This is by far the best of all the spireas for winter-flowering. No other spirea compares freely produced. Case of 100 clumps for $\$ 8.00$; less quantities, $\$ 1.25$ per dozen.

Queen Alexandra. - A new pink spirea. Similar to Gladstone in habit, but flowers are a delicat
rose-pink. Case of 100 clumps for $\$ 10.00$; less quantities, $\$ 1.80$ per dozen.

\section{LILY OF THE VALLEY}

New importation, ready in November

Pierson's Perfection. -This is an extra selected grade for those who desire the finest valley growi. Price of valley has been driven down so low that it has been at the expense of quality, and growers are realizing that a really first-class article cannot he furnished at prices at which valley has been selling. The very best German valley grown has been sent to London and St. Petersburg to growers who have been willing to pay the price for a very superior article, and very few, if any, of the finest pips grown have reached this country; but there is beginning to be a demand here for a better grade of valley than is generally offered, and in order to meet this demand, we are importing this grade of pips, which we have had selected for us with great care, and which are the very finest pips grown. They will produce the largest spikes, with the largest number of bells, and will give the very largest percentage of first-quality. flowers. We can recommend it without hesitation, knowing that it will give perfect satisfaction,

$\$ 2.00$ per $100 ; \$ 16.00$ per $1000 ; \$ 30.00$ per case 2000 pips.

\section{COLD-STORAGE LILY OF THE VALLEY}

We carry only one grade of lily of the valley, and that

The very highest quality obtainable,

for in lily of the valley, as in no other bulb, we have found that the best is the cheapest. Cold-storage valley should always be used for December and early January flowering; for, while new importations arrive in November, the new stock does not force easily or give the requisite amount of foliage so early in the season: so that the cold-storage stock should always be relied upon for December and January forcing. Owing to a severe drouth in Germany last year, extra fine valley is unusually scarce this season. At present we have a good supply, and can ship immediately on receipt of orders; but on acconnt of scarcity of stock, it is advisable to place orders in advance for the quantity desired, which can be reserved, and shipped as wanted. Cold-storage stock must necessarily be shipped by express. It is not safe to ship it hy freight, even short distances.

Cases containing 250 pips, $\$ 5.00$ each. Cases containing 500 pips, $\$ 9.50$ each. Cases containing 1000 pips, $\$ 18.00$ each.

Clumps for Outdoor Planting.-Large clumps, $\$ 2.50$ per dozen, $\$ 15.00$ per 100

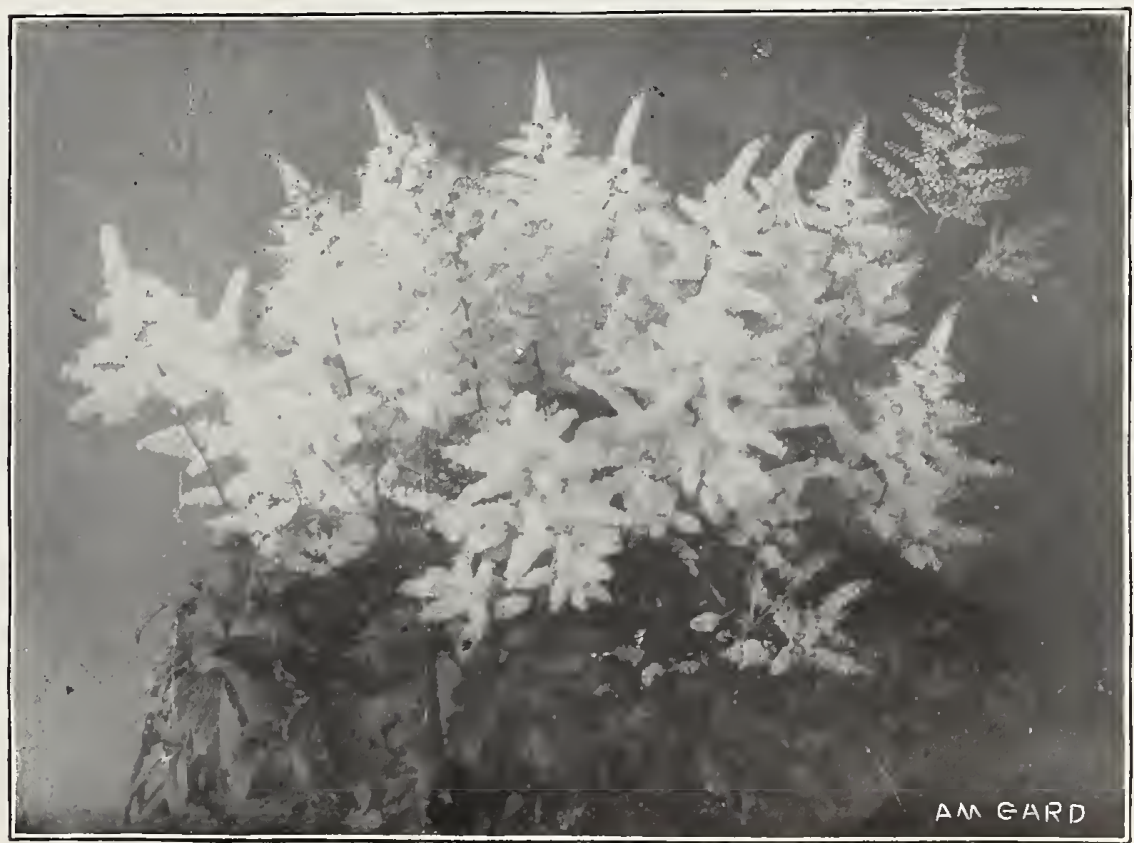

Spirea-Gladstone 


\section{Dutch Hyacinths \\ Ready in September}

\section{SELECTED NAMED}

This is the grade that should be used for pot culture or for growing in pans where flowers of highest quality are desired. The bulbs and finest quality obtainable. The varieties offered are the finest and those best adapted for winter-flowering or bedding, producing the largest and most perfect spikes and the most beautiful flowers.

\section{SINGLE}

Albertine. - Pure white. Large spike. Early..... $\$ 5.50$ Baroness van Tuyll. - Pure white. Large truss. Early 5.00 Chas. Dickens, pink. - Beautiful pink. Finely formed,

Czar Peter. - Light porcelain blue

Gigantea.-Light delicate flesh-pink. Compact spike 5.00

Grand Lilas.-Porcelain lilac. Fine truss and bells... 5.50

Grand Maître.-Deep porcelain blue. Large truss.

Grandeur à Merveille.-Blush white, or light flesh... 5.00

King of the Blues.-Dark blue. Extra large spike... 5.00
Gertrude.-Bright pink. Fine, compact spike.... 7.00

\begin{abstract}
SINGLE
King or 100 King of the Yellows. - Pure yellow. Large bells and
fine spike............................. $\$ 6.00$ La Grandesse. - Pure white. Splendid bells. Large spike 7.00 L'Innocence.-Pure white. Fine, massive spike....6.00 La Peyrouse.-Fine porcelain blue ... . . . 5.00 Marie-Dark blue with purple shade $\ldots . . .50$ Mme. Van der Hoop-Pure white. Large bells . . 5.50 Large bells.... 5.50 Roreno.-Waxy pink. Large bells............. 5.50

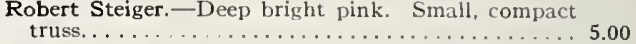
Schotel._Light blue. Fine.................. 5.00 Sonora.-Nankeen y'ellow. Fine, close spike...... 5.50

DOUBLE La Virginite.-Blush white. Extra fine for forcing or bedding 5.00 Othello.-Very dark purple, almost black........... 5.50
\end{abstract}

\section{DOUBLE}

Bloksberg.-Light blue............ Flevo.-Pure white. Large bells. Fine truss. ...... 5.50

Garrick.-Azure blue. Large, compact spike

\section{FINE NAMED}

We recommend this grade particularly for bedding, and it is also very satisfactory for forcing. The bulbs are a size smaller than the Selected Named, but can be offered at only a slight advance over the price of Mixed Hyacinths in Separate Colors, and, consequently, are much more desirable; for when bedded out or used for forcing, they bloom evenly and at one time, while the mixed hyacinths, no matter how carefully selected, bloom more or less irregularly and un evenly.

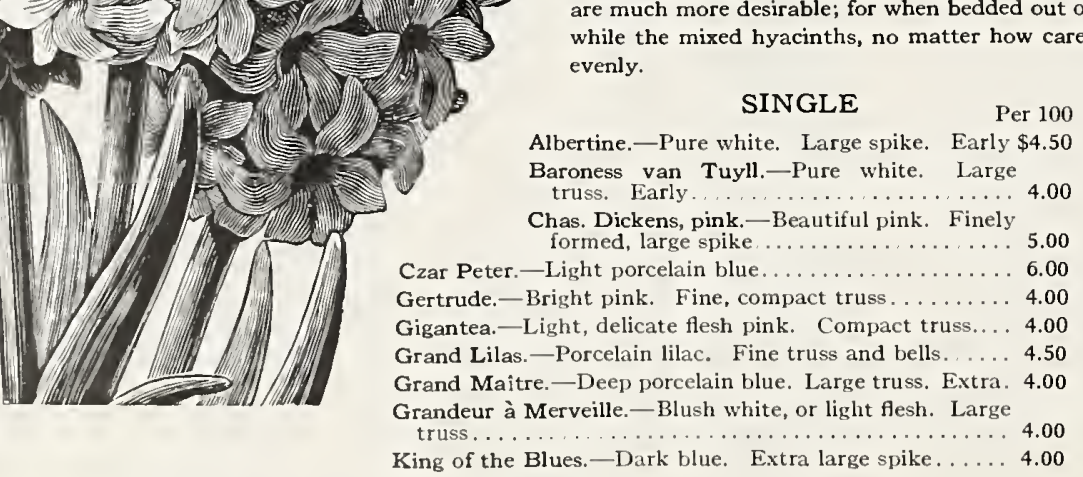

DOUBLE

Bloksberg.-Light blue. Good truss. Bouquet Tendre.-Carmine rose.

Flevo.-Pure white. Large bells. line truss .... Garrick.-Azure blue. Large, compact spike.

\begin{tabular}{|c|c|}
\hline Per 100 & DOUBLE \\
\hline$\$ 4.00$ & La Tour d'Auvergne.-Pure white.. \\
\hline 4.50 & La Virginite.-Blush white. Extra fine for forcing or bedding \\
\hline 4.50 & Othello.-Very dark purple, almost black $\ldots \ldots \ldots \ldots \ldots \ldots$ \\
\hline
\end{tabular}

\section{SINGLE}

King of the Yellows.-Pure Per 100 La Grandesse.-Pure white. Splendid bells. Linnocence.-. Pure white Extra large truss, 5.00 La Peyrouse. - Fine porcelain blue........ 4.00 Marie.-Dark blue with purple shade ......... 4.00 Marie.-Dark blue with purple shade ....... 4.00 Mme. Van der Hoop.-Pure white. Large bells 4.50
Moreno. - Waxy pink. Large bells. Very fine 4.50 Robert Steiger.-Deep bright pink. Small,

4.00 Schotel._Light blue. Fine............. 4.00 Sonora.-Nankeen yellow. Fine, close spike. 4.50

\section{DOUBLE}

Prince of Orange.-Blush rose. Fine spike.
Per 100

$\$ 4.00$

4.00
4.50 4.50

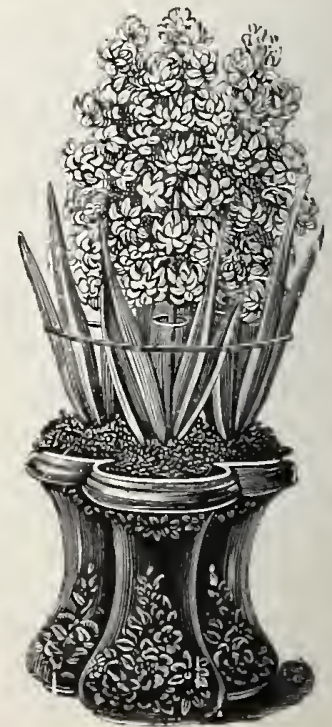




\title{
Dutch Hyacinths
}

\author{
Ready in September
}

\section{SEPARATE COLORS}

These are largely used for bedding, and by many growers are used for forcing, but we do not recommend them for forcing, as nothing but named varietics should be ised for that purpose. We offer the very best quality of these and not the inferior grades which are sometimes offered for less money.

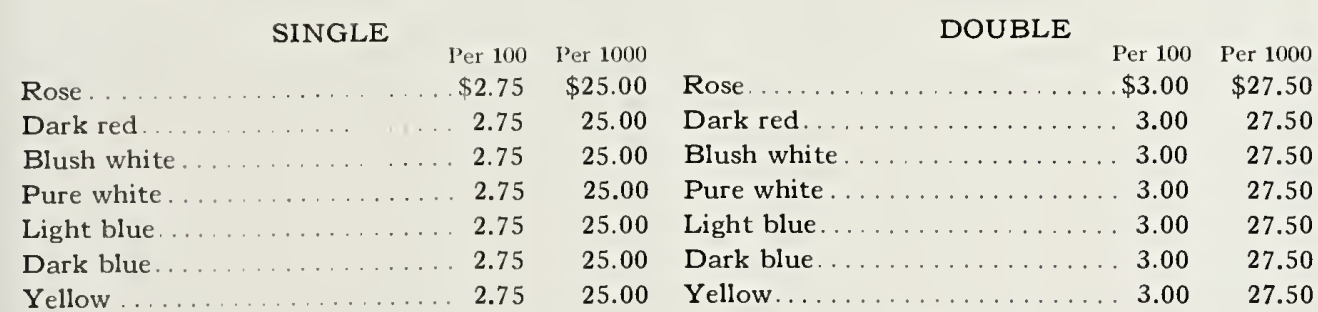

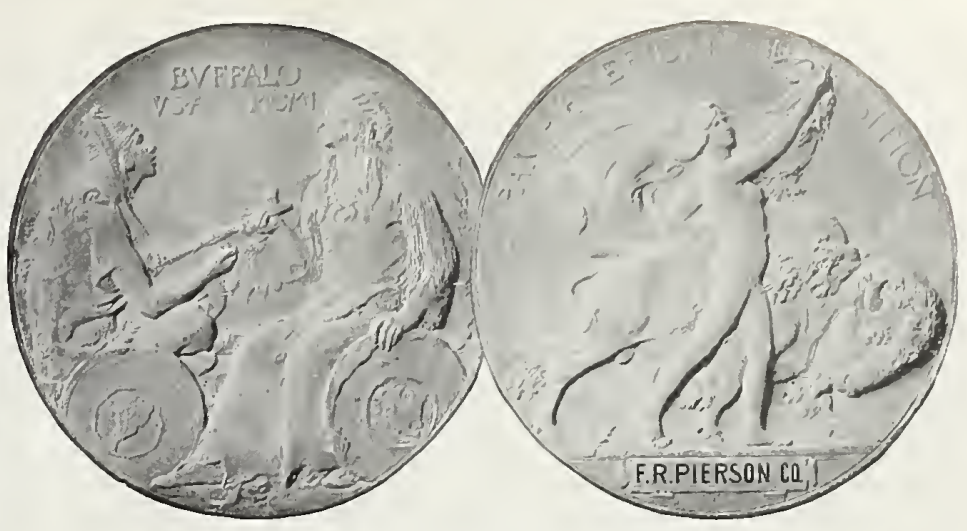

We were awarded GOLD MEDAL, Highest Award, for our Exhibit of Bulbs at the Pan-American Exposition

\section{MINIATURE HYACINTHS, OR DUTCH ROMANS}

\section{Ready in September}

These Dutch Romans are valuable not only for cutting, but also for growing in pans. They can even be lsed for bedding where a cheap hyacinth is desired, producing surprisingly large spikes of bloom, considering the size of the bulbs. We offer only the finest named sorts, which bloom evenly and at one time- those that have becn found most satisfactory for forcing, and those that produce the largest spikes of bloom and of the most desirable colors. The bulbs are of the largest size and of first-class quality, and the prices at which they are offered should not be compared with the prices of inferior grades or of mixtures in separate colors usually offered, which bloom more or less irregularly, while our named sorts bloom evenly and at one time, making them very much more desirable and valuable.

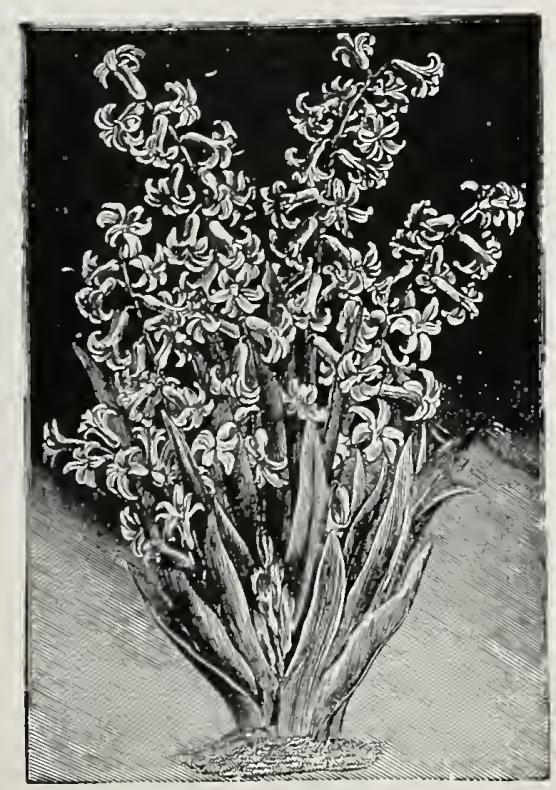

White Roman Hyacinths

\section{EXTRA-SIZED BULBS, 12 TO $14 \mathrm{C} / \mathrm{M}$ IN CIRCUMFERENCE}

Per 100 Per 1000

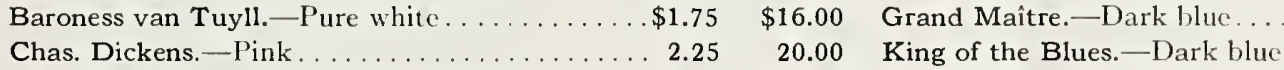

Czar Peter.-Light porcelain blue..........2.25 20.00 L'Innocence.-Pure white; extra fine

Gertrude.-Bright pink

Gigantea.-Delicate flesh-pink.
16.00 La Peyrouse.-Porcelain blue.

16.00 La Grandesse.-Pure white.
Per 100 Per 1000

$\$ 1.75 \$ 16.00$

$1.75 \quad 16.00$

$2.00-18.00$

$1.75 \quad 16.00$

$2.25 \quad 20.00$

FOR GRAPE AND FEATHERED HYACINTHS, SEE PAGE 9

\section{Roman Hyacinths}

Now ready

The bulbs that we offer are of the very finest quality, obtained from the very best sources, carefully packed and graded so that they cannot fail to give the very best satisfaction.

White Romans.-Extra quality bulbs, 11 to $15 \mathrm{c} / \mathrm{m}$ in circumference, $\$ 3.00$ per $100, \$ 28.00$ per $1000 ; 12$ to $15 \mathrm{c} / \mathrm{m}, \$ 3.50$ per $100, \$ 32.00$ per 1000

Pink Romans. - These are somewhat later than White Romans. They are very popular on account of their beautiful color - light flesh-pink. Flowers are semi-double. Extra quality bulbs, 12 to $15 \mathrm{c} / \mathrm{m}$ in circumference, $\$ 2.50$ per $100, \$ 22.00$ per 1000 .

White Italian or Red-skinned Romans. - Very desirable for late forcing, with much heavier flower spikes than White Romans. Extra quality bulbs, 12 to $15 \mathrm{c} / \mathrm{m}$ in circumference, $\$ 2.50$ per $100, \$ 22.00$ per 1000 


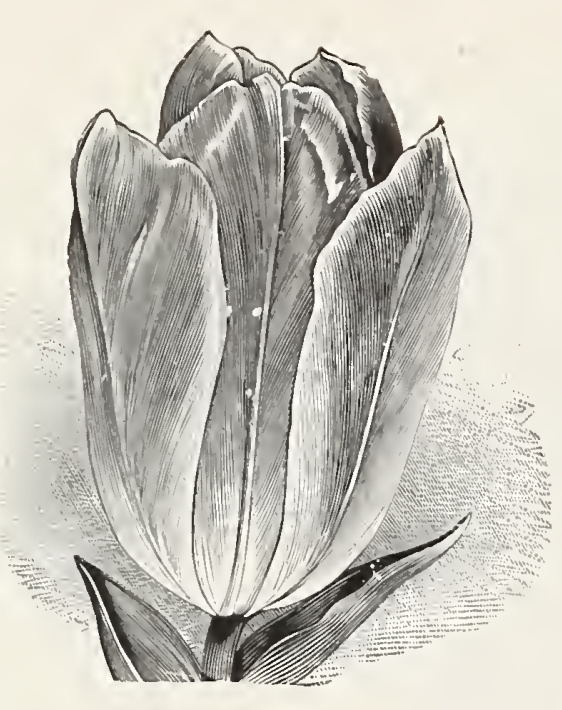

Belle Alliance (Waterloo), - Brilliant scarlet. An extra fine forcing variety. $\$ 1.50$ per 100 ,

Bizard Verdict_-Bright red, feathered, striped, and bordered with bright yellow. A fine variegated Bizard Verdict. ${ }_{\text {tulip. } 75 \mathrm{c} \text {. per } 100, \$ 6.50 \text { per } 1000 .}$

Cardinal's Hat. - Dark brownisly red-somewhat like Brulus, but darker-edge of petals shading to per 1000 .

Chrysolora. - Pure golden yellow; extra large. Finest yellow tulip for bedding. $\$ 1.00$ per $100, \$ 7.50$ Cottage Maid.-An expuisite color-lovely bright pink, heavily marked with white at center and ariet.; can not be forced early. Extra. $\$ 1.00$ per $100, \$ 8,00$ per 1000 , also an extra fine late forcing

Couleur Cardinal. - Dark scarret-crimson. Flower is large, long, and pointed. Extra fine for

Couleur Ponceau. - Bright cherry, base of petals pure white-an exquisite color. A fine bedder.

Cramoise Brilliant. - $\begin{aligned} & \text { - Brilliant scarlet. Very large. Splendid for forcing or bedding. } \$ 1.50 \text { per } \\ & 100,00 \text { per } 1000 \text {. }\end{aligned}$

Crimson King. Crimson-scarlet; very brilliant. Fine bedder, also good for late forcing. $\$ 1.00$ per Duc van Tholl, Scarlet. $\begin{aligned} & \text { Intense dazzling scarlet. Very desirable for early forcing. } \$ 1.50 \text { per } \\ & 100, \$ 12.50 \text { per } 1000 \text {. }\end{aligned}$ Duchesse de Parma. - Orange-red, with yellow edge. Very showy. A good forcer and a fine Joost van Vondel. - Wine color, feathered with white-an unusually striking and distinct color.
Flower very large, with very long stem. Grand. $\$ 1.50$ per 100, $\$ 13.50$ per 1000 .

Keizerskroon (Grand Duc), - Red, heavily bordered golden yellow. Extra large flower. One $\$ 11.00$ per 1000 .

La Reine (Queen Victoria). -White, slightly shaded pink. A favorite forcing variety, and Mon Tresor. - Pure yellow; an extra fine large flower. A little deeper yellow and a little larger flower Pottebakker White. - Finest white forcing tulip; also extra fine for bedding. Extra large fower. Prince of Austria. - Bright orange-scarlet. Strong grower and very large flower. Extra fine for

\section{Tulips \\ Ready in September}

Gold Medal, Highest Award, Pan-American Exposition

for early spring-flowering is increasing from year to year, as nothing that can be planted gives permit the use of named varieties, as a great many of the kinds offered cost only a little on and the fact that they are much more effective when planted separately, we invariably

\section{Single Early Tulips}

Proserpine. - Violet-rose-a lovely color. Extra large and extra fine for early forcing especially, ant
also extra fine for bedding. $\$ 2.25$ per $100, \$ 20.00$ per 1000 .

Rosamundi Huykman.- Rose-pink, with broad white stripe in center of each petal. Large that variety. $\$ 1.00$ per $100, \$ 7.50$ per 1000

Rose Grisdelin.-Best pink tulip for early forcing. Lovely delicate pink-a little lighter than

Rose Luisante.-Superb rose. Very large and extra fine. $\$ 2.00$ per $100, \$ 18.00$ per 1000 .

Thomas Moore. - Apricot-orange or terra-cotta color; very early. The finest orange tulip for Vermilion Brilliant. - Finest of all scarlets for forcing, and the most brilliant of all scarlets. Very White Hawk. - Pure white. Early. One of the finest whites for forcing or bedding. $\$ 1.75$ per 100 , Yellow Prince. - The standard yellow forcing tulip; also fine for bedding. When bedded shows faint

Finest Mixed. -The mixed tulips offered by us are much superior to ordinary mixtures, being nade colors. We can recommend this mixture to any one wanting mixed tulips. $\$ 1.00$ per $100, \$ 7.50$ per 1000

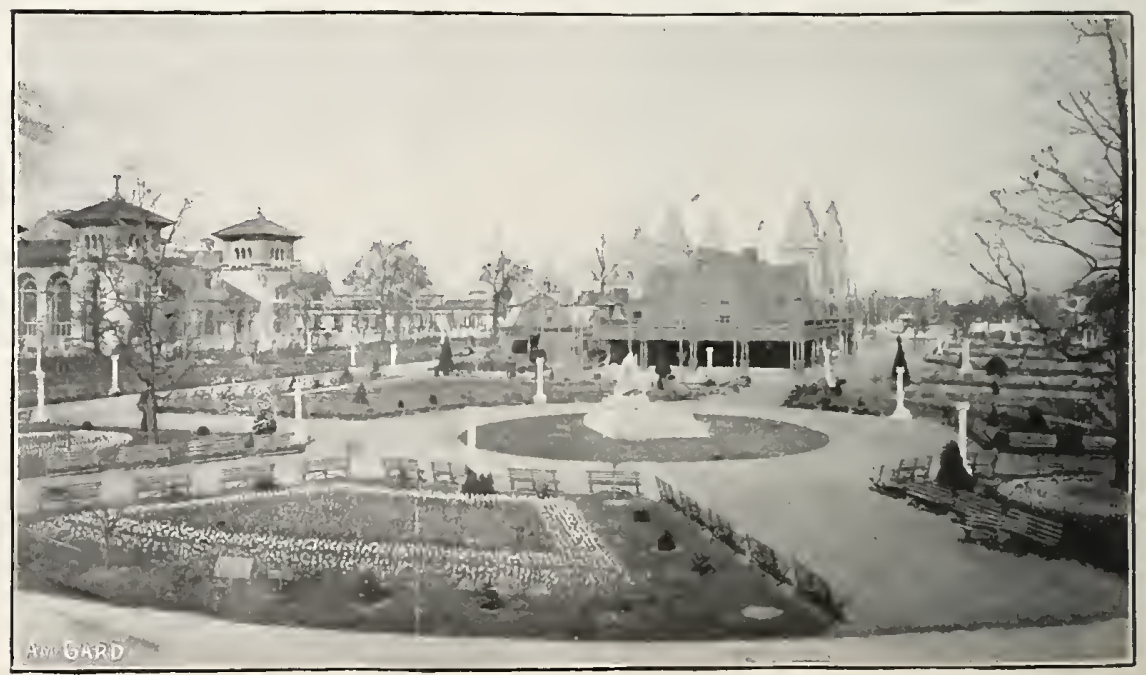




\section{Single Late Tulips}

These late-flowering tulips are very desirable on account of their late season of blooming and their howy flowers. They bloom after the early'flowering ulips are gone, and the flowers are exceedingly showy. middle to he end of Mlay, depending on the seatson and locality. In some localities they are in bloon as ate as Decoration Day. As they bloom year after year, they should he planted where thcy will not be

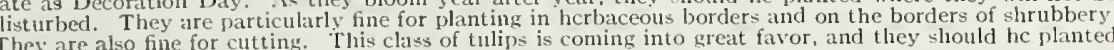
more largely than they have been.

\section{DARWIN}

Baronne de la Tonnaye. - ${ }_{\text {per }} 100$.

Bartigon.-Bright red, sliaded rosc. \$2.50 per 100.

Clara Butt. -Beautiful clear salmon-pink. $\$ 3.00$ per 100.

Dream. Dark lilac-lavender. \$2.25 per 100.

Europe. - Salmon-scarlet, onter petals shatled carmine, $\$ 2.50$ per 100.

Flambeau. - Dark carmine-rose. $\$ 2.00$ per 100.

Gretchen (Margaret).-Silvery pink. \$1.50 per 100

May Queen.--Soft rose. $\$ 2.00$ per 100.

Mme. Krelage. - Bright rose, changing to silvery rose. $\$ 2.50$ per 100

Mr. Farncombe Sanders. - Bright carmine-scarlet. Tall grower. Very fine large flower Mrs. Stanley.-Y'iolet-rose. \$2.50 per 100.

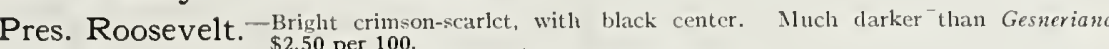
Prof. Francis Darwin.--Briglt carmine rose. $\$ 2.50$ per 100.

The Sultan.-Blackislı maroon. $\$ 1.50$ per 100.

White Queen (La Candeur).-Whitc, tinged lavender, \$2.25 per 100.

Finest Mixed. - All colors. $\$ 1.50$ per $100, \$ 10.00$ per 1000.

\section{MAY-FLOWERING, OR COTTAGE}

Bizards. - Flowers beautifully blotched, striped, and feathcred with crimson, pink, scarlet, rose, lilac . Byblooms. - Filowers beautifully blotched, striped, and featlered with crimson, pink, scarlet, rose, Bouton d'Or. - Pure golden yellow. Very showy. Extra fine. Very tall. $\$ 1.50$ per 100, $\$ 11.00$ per Elegans lutea. - Straw color. Pointed petals, Very distinct. \$2.75 per 100.

Gesneriana lutea. - Bright golden yellow. Very late. $\$ 1.50$ per 100 .

Gesneriana Spathulata. - The true Gesneriana. Finest of all late tulips. Dark brilliant scarlet, with black center. Very large. $\$ 1.50$ per $100, \$ 12.00$ per 1000

Golden Crown. - Yellow, edged scarlet. Very showy. Sometimes called the Yellow Gesneriana. Inglescombe Pink.-Violet-rose. $\$ 2.00$ per 100

Isabella. - Briglt carminc-pink, white toward base of petals. A beautiful variegated flower. $\$ 1.50$ Parisian Yellow.-Colden-yellow; outside of petals buff, Pointed flower, \$2.00 per 100.

Picotee (Maiden's Blush). - White, delicately edged rose. A very beautiful tulip. $\$ 1.50$ per Summer Beauty (Striped Beauty). - Bright carmine-rose, feathered white. A beautiful

\section{PARROT}

Admiral of Constantinople. -Orange-scarlet. $\$ 1.00$ per $100, \$ 8.00$ per 1000 Lutea Major. -Golden yellow. $\$ 1.00$ per $100, \$ 8.00$ per 1000.

Markgraff van Baden. - Orange-yellow, outsidc of petals striped scarlet. $\$ 1.25$ per $100, \$ 9.00$ Perfecta.-Yellow, striped scarlet. $\$ 1.00$ per $100, \$ 8.00$ per 1000 .

Finest Mixed.-All colors. $\$ 1.00$ per $100, \$ 7.00$ per 1000.

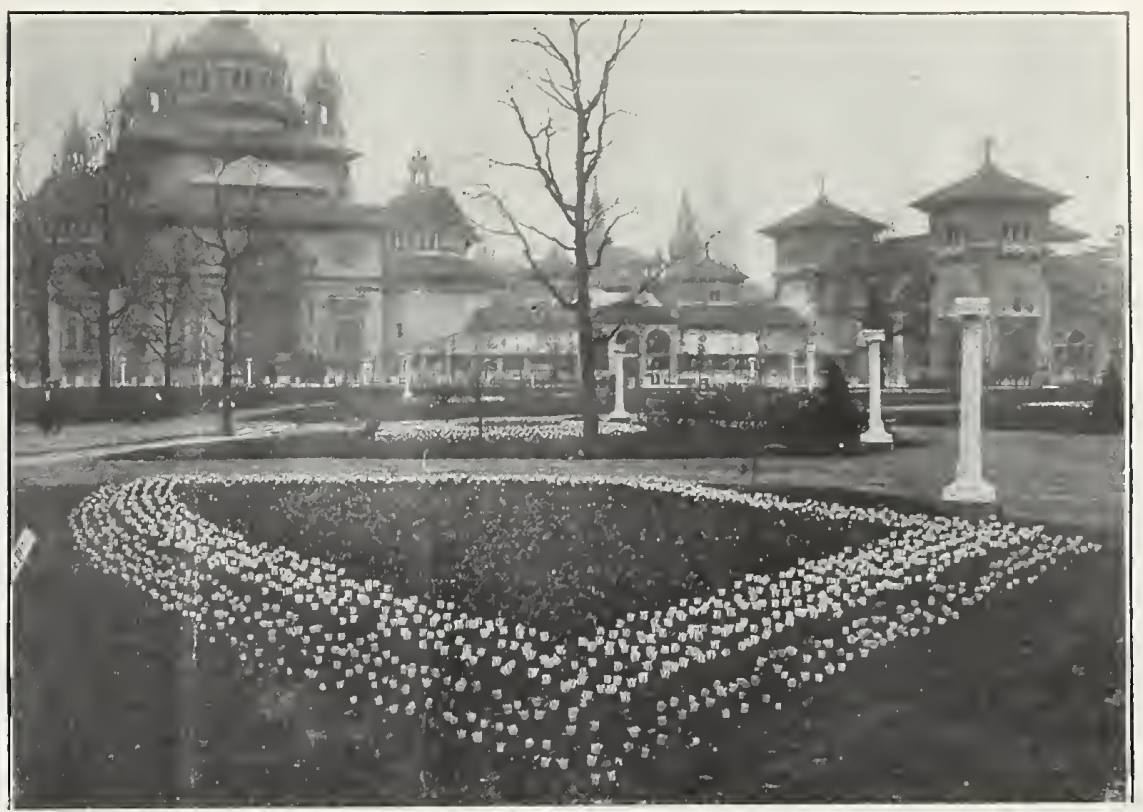

\section{Double Tulips}

Count of Leicester. - Orange-yellow. Earlicr than Yellow Rose. $\$ 1.00$ per 100, $\$ 8.00$ per 1000. Couronne d'Or.-Yellow, shaded orange. Extra fine for forcing. $\$ 2.00$ per $100, \$ 17.00$ per 1000 .

Duke of York.-Carmine, edged white. Good for forcing. $\$ 1.00$ per $100, \$ 8.50$ per 1000. Gloria Solis. - Crimson, with yellow margin. Fine bedder; one of the showiest tulips for this purpose; be forced so early. $\$ 1.25$ per $100, \$ 11.00$ per 1000 .

Imperator Rubrorum. - Very fine bright scarlet. Finest of all douhle scarlets for forcing. $\$ 1.75$ La Candeur. - Pure white. Fine for bedding, and also for Easter forcing. \$1.25 per 100, \$9.50 per Murillo. - A magnificent flower, blush white, shaded rose, Large fine flower. Extra for forcing. \$1.00 Rose Blanche.-Pure white. Very early; earlier than La Candeur. $\$ 1.00$ per $100, \$ 8.00$ per 1000 .

Rubra Maxima. - Fine scarlet, darker than Rex Rubrorum. Extra for forcing or bedding. $\$ 1.25$ Salvator Rosa. - Deep rose, flamed white. IIighly reconmended for very early forcing. $\$ 1.75$ per
$100, \$ 15.00$ per 1000 . Tournesol Red and Yellow. - Scarlet, bordered yellow. Extra fine for forcing. Exccedingly Yellow Rose.-Bright yellow. Late. $\$ 1.00$ per $100, \$ 8.00$ per 1000

Finest Mixed. - Extra choice mixture from named varieties. All colors. $\$ 1.00$ per $100, \$ 8.00$ per
1000 . 


\section{Narcissus}

Ready in September

\section{LARGE SINGLE TRUMPETS}

Victoria. - Grand new bicolor. A variety of great merit. Petals broad and flat, with bold yellow . Selected double-nosed bulbs, $\$ 2.00$ per $100, \$ 18.00$ per 1000 .

Empress. - A magnificent variety, white perianth with rich yellow trumpet. Flowers large and of great per 100, $\$ 12.50$ per 1000 . Selected double-nosed bulbs, $\$ 2.00$ per $100, \$ 17.00$ per 1000 .

Emperor.-Deep yellow trumpet, sulphur perianth. Immense. The finest of this section. First sized

Golden Spur - A magnificent single trumpet narcissus, with enormous flowers of deep golden yellow A bulbs, $\$ 2.25$ per $100, \$ 21.00$ per 1000

Princeps. (The large Irish Single Yellow Trumpel Daffodil). - Magnificent large blooms; light sulphurfor florists on account of its earliness and the low price at which the bulbs can be offered. Selected mammoth double-nosed, or top-root, bulbs, $\$ 1.25$ per $100, \$ 10.00$ per 1000

Single Von Sion. - We recommend this strongly in place of Trumpel Major, especially for early flower, and a much better bloomer. The best pure yellow moderate-priced single trumpet narcissus. $\$ 1.25$ per $100, \$ 9.50$ per 1000

\section{DOUBLE-FLOWERED}

Double Von Sion, or Double Yellow Daffodil. ${ }^{\text {is }}$ This of the most useful and profitable of winter-flowering bulbs, and is forced in large quantities. There is nothing in which quality is so important as in Von offer is the pure rolden yellow. Those who have been troubled with "Green Von Sions" should try our stock. Growers will find it will pay to buy the best

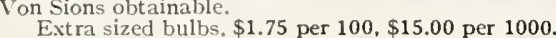

Extra sized bulbs, $\$ 1.75$ per $100, \$ 15.00$ per 1000 .
Selected mammoth double-nosed, or top-root, bulbs, $\$ 2.50$ per $100, \$ 22.00$ per 1000 .

Alba Plena Odorata.-Double; pure white gardenia-like flowers, per 1000 .

Orange Phoenix. - Double white flowers with orange nectary. $\$ 1.25$ Silver (Sulphur) Phoenix. - Sulplur white. Extra fine. $\$ 1.50$

\section{CHINESE SACRED LILY}

A favorite bulb for retailing, as it makes a fine house-plant, and is one of the best selling hulbs for this purpose. We offer the finest quality bulbs. flowers. Single basket (30 bulbs), \$1.20. Original bundle, proning ou baskets ( 120 bulbs), $\$ 4.20$.

\section{PAPER-WHITE GRANDIFLORA}

Now ready

Much larger and better than the ordinary variety, blooming in larger very finest quality obtainable. Extra quality bulbs, $13 \mathrm{c} / \mathrm{m}$ and up in circumference, $\$ 1.25$ per 100 ,
$\$ 9.00$ per 1000 . Selected quality bulbs, $11 \mathrm{c}$ ' $\mathrm{m}$ and up in circumference, $\$ 1.50$ per $100, \$ 11.00$ per 1000 .

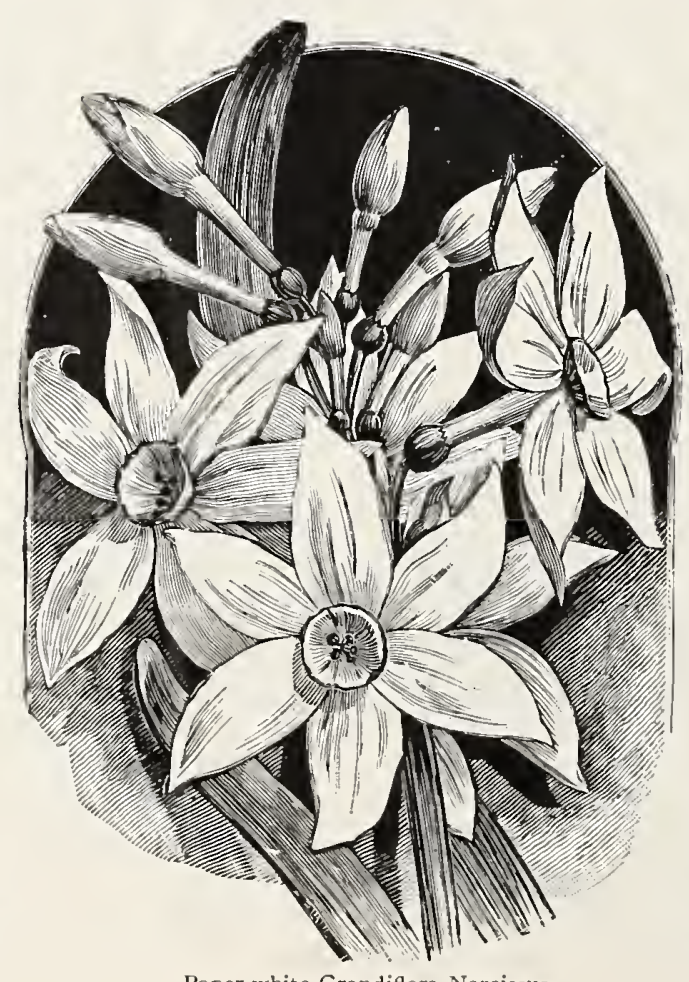

Paper-white Grandiflora Narcissus

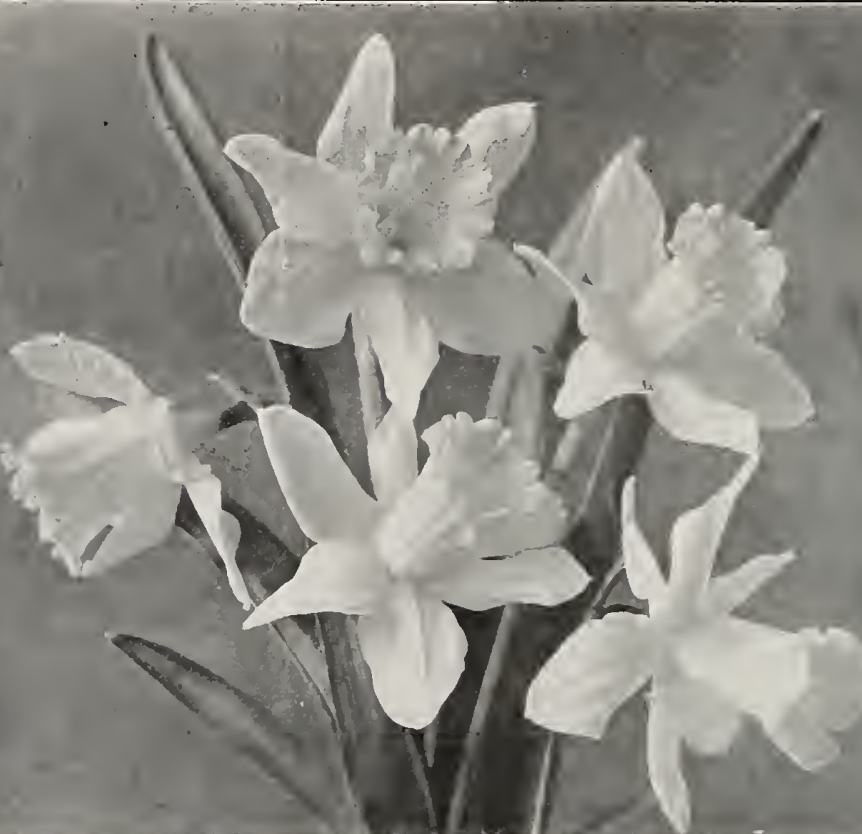

Empress Narcissus

\section{MISCELLANEOUS SORTS}

Mrs. Langtry. - The finest of the Leedsii type. Broad white prtals. . tor excedingly valuable for cutting. $\$ 1.00$ per $100, \$ 7.00$ per 1000 .

Barri Conspicuus. - Beautiful canary-yellow, with deep golden cup. hree and a half inches in diameter borne on long stems. Fine for forcin or outdoor planting. $\$ 1.00$ per $100, \$ 7.00$ per 1000 .

Poeticus. (Pheasanl's-eye).-Pure white, with red cup. Very usefu doors, where it is perfectly hardy and will bloom year after year. 75c. per $100, \$ 5.00$ per 1000

Poeticus Ornatus. - The Improved Poeticus. Pure white, with scarle Poelicus. A magnificent cut flower. This is becoming more and more largely used for forcing. Double-nosed bulbs, $\$ 1.00$ per $100, \$ 7.50$ per 1000

\section{JONQUILS}

Giant Campernelle Jonquil Rugulosus.-Much larger Giant Campernelle Jonquil Rugulosus. - Mhd her than

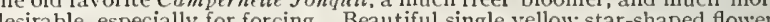
beautifully imbricated, borne in clusters of four to six on a stem, deliglut fully ragrant. Also very hardy, and invaluable for outdoor planting. $\$ 1.00$ per $100, \$ 7.00$ per 1000

Double Jonquil. - Bears clusters of small, very double, deep golden for forcing and outside planting. $\$ 2.00$ per $100, \$ 15.00$ per 1000 . 
ALLIUM NEAPOLITANUM

75e. per $100, \$ 5.00$ per 1000 .

\section{ANEMONES}

The Bride.-Single. Pure white. 65c. per $100, \$ 5.00$ per 1000. Single.-. Ill colors mixed. $65 \mathrm{c}$, per $100, \$ 5.00$ per 1000 .
Double.-All colors mixed. $\$ 1.00$ per $100, \$ 7.50$ per 1000.

\section{CHIONODOXA LUCILIAE}

Deej) blue, with white center. 80e. per 100, $\$ 6.50$ per 1000.

\section{DIELYTRA SPECTABILIS}

Ready in November

Strong clu11ps. $\$ 1.00$ per dozen, $\$ 6.00$ per 100 .

\section{GRAPE AND FEATHERED HYACINTHS}

Blue Grape.-50c. per 100, $\$ 4.00$ per 1000 . Feathered. - 80c. per 100, $\$ 5.00$ per 1000 .

\section{SPANISH IRIS}

Fine for late forcing; can be had in flower early in April. Also good for outdoor culture, flowering in the open ground in June, requiring only a slight covering in winter. Claimed by many to he
entirely hardy. They are so beautiful they should be extensively entirely:
planted.

Belle Chinoise.-Bright golden yellow. Early. Best early sort British Queen.-Early. White. Finest whit

75 c. per $100, \$ 5.00$ per 1000

Extra fine mixed varieties. All colors. 40c. per $100, \$ 3.00$ per 1000

\section{IXIAS}

Finest Mixed.-Very showy and brilliant; well adapted for cut $50 \mathrm{e}$ per $100,53.50$ per 1000 . Spldid new large flowering varietic

\section{OXALIS}

Bermuda Buttercup. - This has met with a very large sale, as it is an ideal house plant. Blooms all winter long. Flowers are of good size; bright golden yellow. We offer ext
stock. $\$ 1.25$ per $100, \$ 9.00$ per 1000 . Alba.-White. $\$ 1.00$ per 100.

Boweil--Pink, large, $\$ 1.00$ per 100.

\section{DOUBLE RANUNCULUS}

French.-All colors mixed. 60c. per 100, $\$ 4.00$ per 1000 Turban.-All colors inised. 65c. per 100, $\$ 5.00$ per 1000.

\section{SCILLA}

Siberiea.-Bright blue; early. 75c. per $100, \$ 6.00$ per 1000 Campanulata cerulea. - Blue; tall. $65 \mathrm{c}$. per $100, \$ 4.50$ per 1000

\section{SNOWDROPS}

$$
\text { (Galanthus) }
$$

Single. -65 e. per $100, \$ 5.50$ per 1000 .

Gouble. $\$ 1.25$ per $100, \$ 9.00$ per 1000.

\section{SPARAXIS}

50c. per $100, \$ 3.50$ per 1000 .

\section{Crocus}

Ready in September

\section{MAMMOTH BULBS}

These are extra large selected bulbs, averaging $11 / 4$-in. and up in diameter. Varieties 等 flowers.

Baron von Brunow.-Dark purple.

Purpurea Grandiflora.-Dark purple; very

David Rizzio.-Dark blue. largest size. Magnificent.

La Majestueuse.-Violet, striped white.

Queen of the Netherlands.-. Pure white, fine large flower. Extra fine. Flowers very freely.

Mont Blanc.-Snowy white.

Sir Walter Scott.-Violet, striped white.

$$
\text { 75e. per } 100, \$ 6.50 \text { per } 1000 .
$$

SEPARATE COLORS.-Blue, White, Yellow, Striped. $75 \mathrm{c}$, per $100, \$ 5.00$ per 1000.

\section{Forcing Gladiolus}

\section{Ready in November}

Colvilli alba "The Bride."-Pure white flowers. Dwarf col habit. This is being more and more largely planted, as it is one of the most useful cut flowers 75e. per 100 , $\$ 5.50$ per 1000 .

Blushing Bride. - A splendid new forcing variety. Blooms pure white, with pink markings. Very desirable and valuable. $75 \mathrm{c}$. per $100, \$ 5.50$ per 1000 .

Peach Blossom. - Flowers a beautiful shade of pink. Belongs blooms six weeks before Colvilli alba. $\$ 1.25$ per $100, \$ 9.00$ per 1000 .

America. - The peer of all gladiolus. It forces easily, and is the Are most profitable variety for that pur pose. Flowers cattles. Its fine color makes it a ready seller at big prices. For florists' use for summer flowers it is without a rival. $\$ 2.50$ per 100 , $\$ 20.00$ per 1000

Augusta. - Another favorite forcing variety. Lovely pure white,
with blue anthers. $\$ 2.50$ per $100, \$ 20.00$ per 1000.

\section{GLADIOLUS \\ FOR OUTDOOR PLANTING}

Ready in December

White and Light. $\$ 2.00$ per $100, \$ 15.00$ per 1000 .

Scarlet and Red. $-\$ 1.50$ per $100, \$ 12.00$ per 1000 .

Yellow and Orange. $-\$ 3.50$ per 100.

Pink and Rose. $-\$ 2.00$ per $100, \$ 15.00$ per 1000 .

Striped and Variegated. $\$ 2.50$ per $100, \$ 20.00$ per 1000 .

Groff's Hybrid Seedlings.-All colors mixed; the most popular strain

Childsi.-Giant hybrids, mixed. $\$ 2.00$ per $100, \$ 15.00$ per 1000 . Lemoine's Hybrids. - Finest mixed. \$1.50 per 100, \$12.00 per 1000 . Extra Superfine Mixed.— $\$ 1.50$ per 100 , $\$ 10.00$ per 1000 .

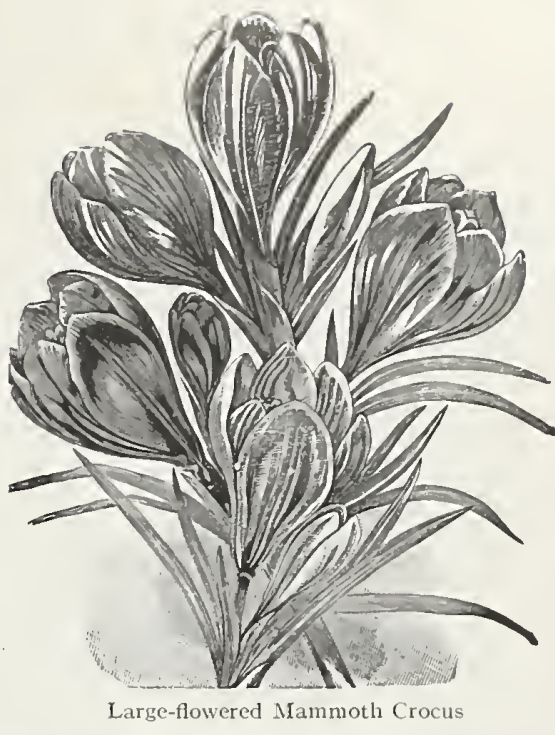

\section{TUBEROUS-ROOTED BEGONIAS}

Ready in December

We offer these at unusually low prices. Bulbs are first-class, rumning $11 / 4$-in. diameter and up. The quality of the flower, notwithstanding the low price, is unusually fine. There is no finer stock to be had in Europe. Buyers will find it cheaper to buy here at our prices than to import their own stock direct.

Separate eolors.-White, pink, scarlet, yellow, and crimson.

Double. $-\$ 4.00$ per $100, \$ 35.00$ per 1000 .

Single. $-\$ 2.50$ per $100, \$ 22.50$ per 1000 .

\section{GLOXINIAS}

Ready in December

We handle these very largely, and our strain of Hybrida Crassifolia Erecta Grandiflora is unequaled, embracing an unusual proportion of spotted, white, pink, and other choice colors. Bulbs are of large size.

Finest Mixed. $\$ 3.00$ per $100, \$ 25.00$ per 1000 .

Separate Colors. -White; red; blue; blue, bordered white. \$3.50 per 100.

\section{CALADIUM ESCULENTUM}

Ready in December

Bulbs 6 to 9-in. in circumference, $\$ 3.00$ per $100, \$ 25.00$ per 1000 . Bulbs 9 to 12 -in. in circumference, $\$ 6.00$ per $100, \$ 50.00$ per 1000.

\section{TUBEROSE PEARL}

Ready in December

Our bulbs are grown in the South, where the climate and soil are peculiarly adapted for their perfect development, and the stock we offer is the finest to be had anywhere.

Extra quality bulbs, $\$ 1.00$ per $100, \$ 8.50$ per 1000 


\section{Azaleas}

\section{Ready in October}

Xext to the Easter lily, these are the most inportant plants for Easter decoration. We shall have to offer in October and Novenber

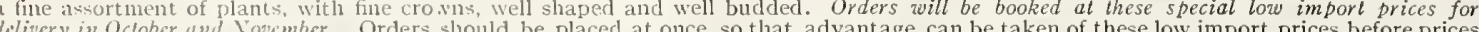
urlvance later in the seasing Wress and at a grent saving in cost of transportation. These prices will hold good only for early shipment, as we can not afford to sell at

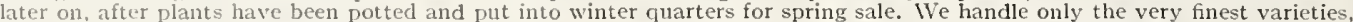
purposes or private conservatories.

Empress of India. - Double. Variegated white and salmon

Ernst Eckhaute.-Double. Bright amaranth.

Mme. Joseph Vervaene.- Very large double flower

111irgin. Late. The finest of all in this color for Easter.

Mme. Petrick.-Double. Bright rose. Very early.

Mme. Van der Cruyssen.-Double. Bright rose
Niobe. - Double. Pure white, with finely crinkled edges. A fine

Pharailde Mathilde.-Double, White. Early.

Simon Mardner. - Very double. Bright silvery rose; a Very early.

Vervaeneana.-Double. Rosy salmon, with white margin.

Vervaeneana alba.-Pure white. A sport from Verrespect excent color.

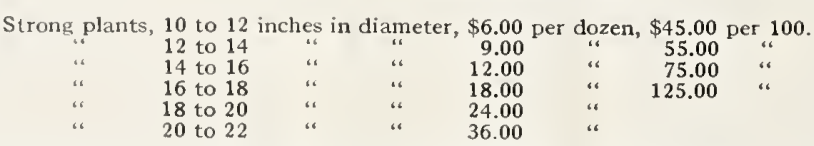

DWARF, OR MINIATURE, AZALEAS

These dwari azaleas, which have been grown as novelties for the past year or two, are rapidly coming into favor, and are now in great

Firefly, or Hexe.-Very brilliant crimson. Splendid. Chas. Encke,-Beautiful slade of pink and white.

$\$ 4.80$ per dozen, $\$ 35.00$ per 100 .

\section{AZALEA MOLLIS}

This is largely used in Europe, and is being more largely us

Fine bushy plants, well budded, 12 to 15 inches high, $\$ 6.00$ per dozen, $\$ 40.00$ per 100 .

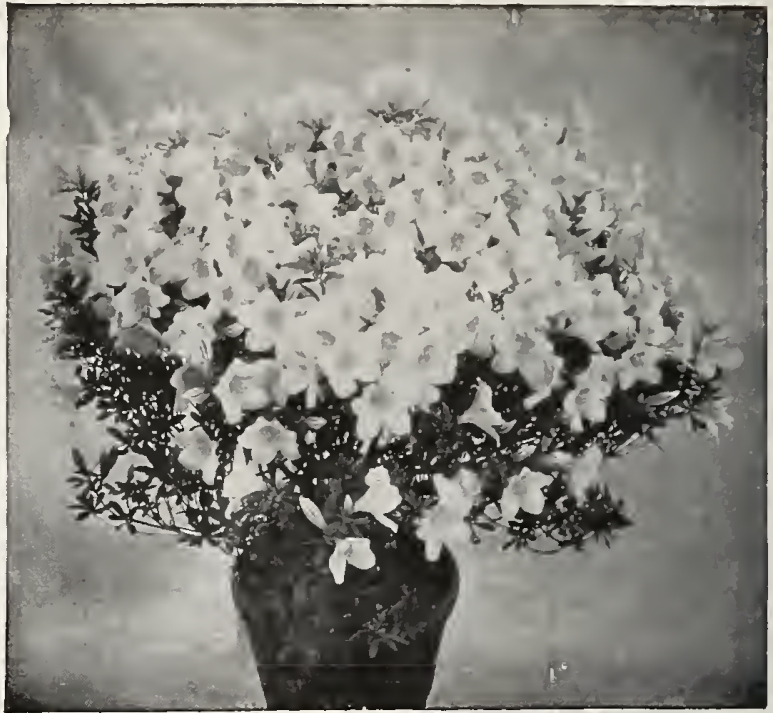

\section{POT-GROWN LILACS}

Ready in November

We offer the best varieties for forcing for winter flowers.

Souv. de Louis Spath.--Single purple.

Marie Legraye.--Single white. Very free bloomer.

Mme. Lemoine.-Double white. Truss very large and compact.

Charles X.-Single blue. Large truss.

Extra fine plants, well budded, $\$ 12.00$ per dozen.

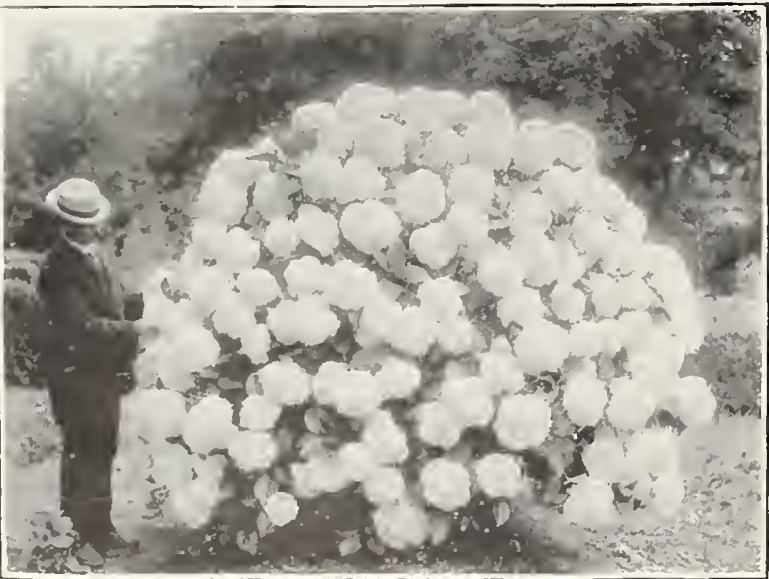

HYDRANGEA OTAKSA

Strong dormant plants, ready in November. 4-inch pots, $\$ 6.00$ per 100 ; 6 -inch, $\$ 25.00$ per $100 ; 8$-inch, $\$ 6.00$ per dozen; very large plants in 14 -inch cypress tubs with her dozen; very large plants in $14-$ inch cypress tubs with handles, $\$ 2.00$ and $\$ 3.00$ each; extra larg
half barrels, $\$ 5.00, \$ 7.50$ and $\$ 10.00$ each.

\section{Hydrangeas for Easter Forcing}

These are becoming more and more important plants for Easter, spring, and summer flowering, and the new French varieties have increased the interest in these exceedingly valuable and profitable florists' plants.

\section{NEW FRENCH HYDRANGEAS}

We offer a few of the best of the new French varieties, which are very much in demand on account of their great superiority.

Avalanche.-Splendid large white flower. Very easily forced. Strong plants, 4 -inch pots, $\$ 10.00$ per $100 ; 8$-inch, $\$ 6.00$ per dozen.

Fraicheur. - IVhite, delicately suffused with rose. Strong plants, 4 -inch pots, $\$ 10.00$ per $100 ; 8$-inch, $\$ 6.00$ per dozen.

La Lorraine.- Very large flower, pale rose, turning to brigh pink. A general favorite. Strong plant 4 -inch pots, $\$ 10.00$ per $100 ; 8$-inch, $\$ 6.00$ per dozen.
Mme. Maurice Hamar. - Very bright pink. Vigorou Mrower. Both individual flower and truss are very large. One of the easiest to force early. Stro

Mme. E. Mouillere.-Extra fine in every way: Pure very large trusses. Strong plants, 4 -inch pots, $\$ 15.00$ per 100 -inch, $\$ 9.00$ per dozen. similar to Ime. E Mouillere There is a difference of opinion among growers as to which is preferable. Some conside this the hetter variety. Strong plants, 4 -inch pot<, $\$ 15.00$ per 100
Mlle. Renee Gaillard. - Yery large panicles of milky white 


\section{New Rose, Killarney Brilliant}

The Most Valuable Rose Introduced in Many Years.

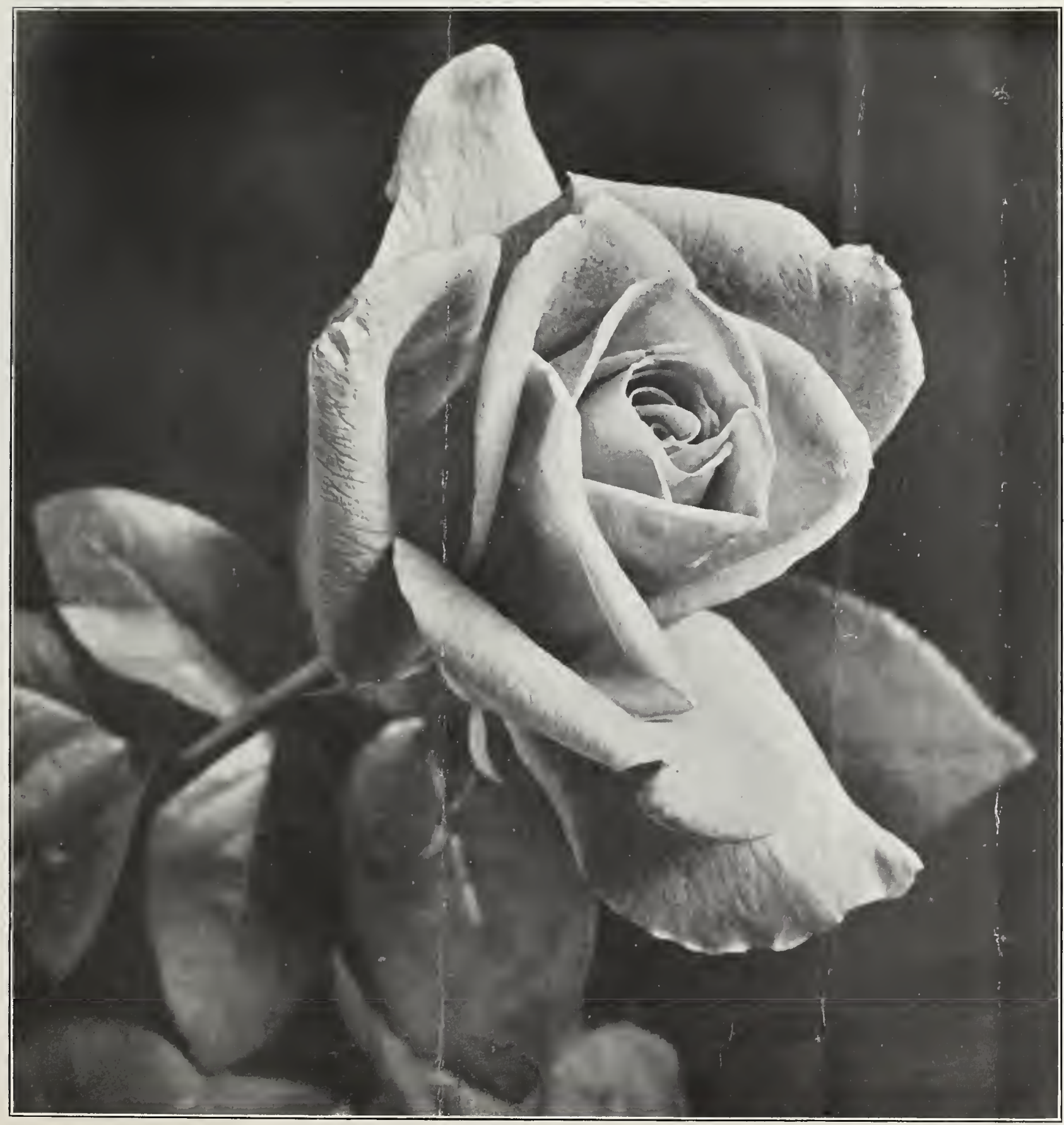

We consider this new rose-a sport from the original pink Killarney-the most valuable rose that has been introduced in many years. It is well named Killarney Brilliant, on account of its brilliant color.

It is a great improvement on the original pink Killarney; first, because of its much more brilliant color, it being almost crimson in bright weather, while in midwinter-in clull, cloudy and foggy weather, - when the original pink Killarney loses its brilliancy and becomes badly faded, Killarney Brilliant is as bright and deep a pink as the original varicty at its best. In addition to its great superiority in color, the flower is almost twice as large, having from twenty-five to forty full sized petals.

It has the same desirable color that Killarney Queen possesses, but has double the number of petals, making it a very double and a fuller flower; and it is also very much more productive, having the same habit of growth and the same freedom of bloom as its parent.

We have watched Killarney Brilliant growing during the past winter, planted in the same house with the original and the double pink Killarney, and when those varieties faded so as to be almost unmarketable, Killarney Brilliant was superb. We are thoroughly convinced that it will immediately supplant the original killarney as the standard market variety, and that every up-to-date grower will be compelled to plant it, on account of its great superiority. A prominent rose grower. who has seen it growing, says it is the only. rose he has ever seen that needs no advertising: it sells itself.

Ready for delivery March, 1914 Strong grafted plants, $\$ 7.50$ per dozen, $\$ 35.00$ per $100, \$ 300.00$ per 1000 .

Own-root plants, $\$ 6.00$ per dozen, $\$ 30.00$ per $100, \$ 250.00$ per 1000 
Wholesale Price List of Bulbs, Etc. F. R. Pierson Co., Tarrytown-on-Hudson, N. Y.

\section{New White Carnation, Matchless}

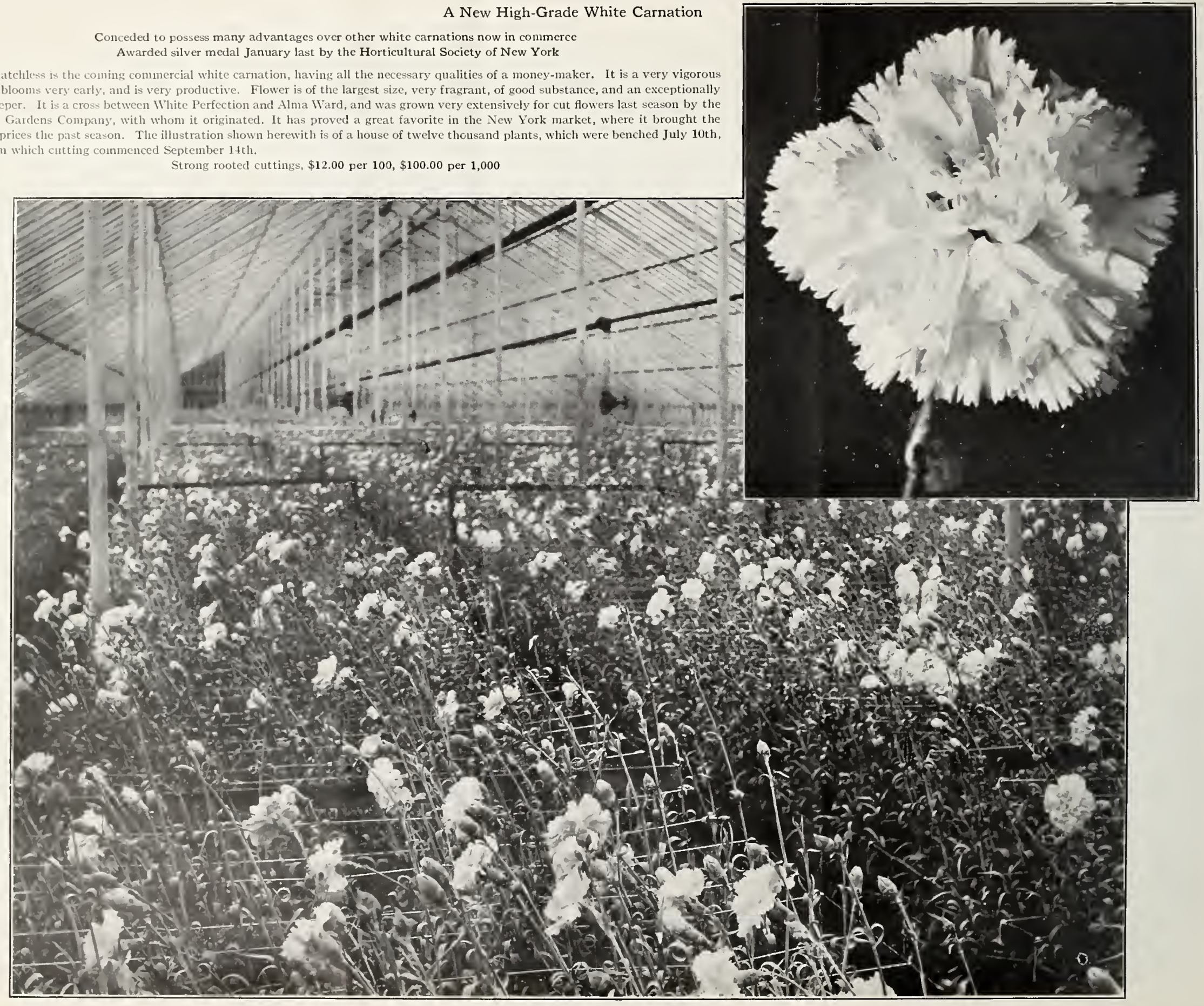




\section{NEW CRIMSON CARNATION}

\section{PRINCESS DAGMAR}

A carnation that attracts instant attention on account of its mainmoth size. flowers measuring three and a half to four inclses in diameter. Flowers very dark crimson, borne on strong, stiff stems, which hold them perfectly erect. Calyx seldom splits. This variety was raised by Patten \& Company, and the phenomenal cliaracter of the awards that it las received indicates its high quality better than any description can. It was awarded a silver medal by the Massachusetts Horticul tural Society: Boston; gold medal. International Flower Show, New lork: silver medal, Perpetual Flowering Carnation Society. England bronze medal, American Carnation Society; bronze medal, Chicago Horticultural Societ $y$.

Strong rooted cuttings, $\$ 12.00$ per $100, \$ 100.00$ per 1000 .

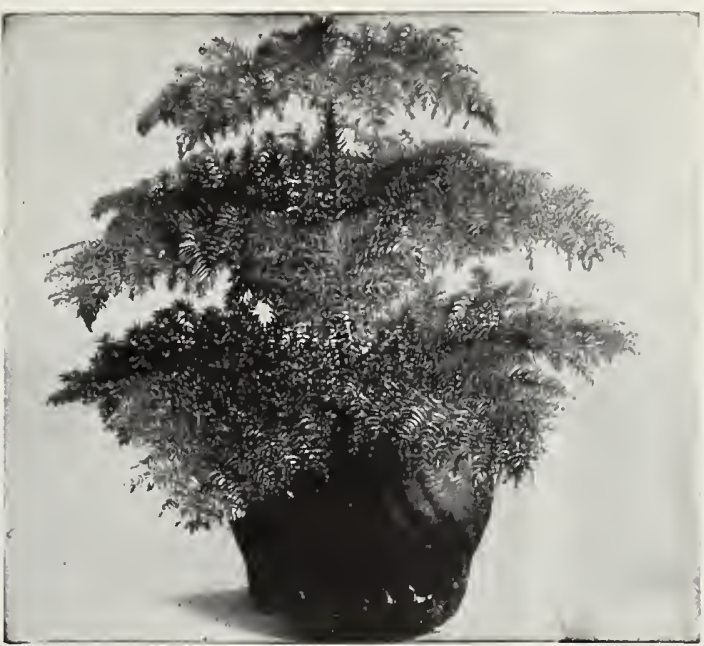

Araucaria

\section{ANTIRRHINUM (Snapdragon)}

The improved snapdragons are very desirable and very jofofitable forists' flowers, and are beginning to attract a great deal of attention. Under glass in winter they flower from October to summer, and they also be grown in the open ground, flowering all summer. We offer wo of the very best varietics.

Buxton's Pink - We exhibited a vase of this variety at the 's Pink. National Flower Show in New York last spring and it was one of the most attractive flowers on exhibition. Every one was charmed with it, and we were surprised at the demand for it. Any one who grows this for winter flowers will find it a very salable flower and a very profitable article. It produces large spikes of bloom thirty inches in length, of a most exquisite shade of silvery pink, borne on long stems. It blooms very freely.

Phelps's Winter-flowering White.-An extra choice that should be grown as a companion to Buxton's Pink. Indispensable to the retail florist.

Strong plants from $21 / 4$-inch pots, $\$ 5.00$ per 100

\section{Palms and Decorative Plants}

\section{ARAUCARIA EXCELSA}

These plants are in demand at the holidays, at which time they make beautiful plants for table decoration. Profitable pliuts at all times.

Strong plants, $2 \mathrm{ft}$. high, $\$ 1.50$ each; $21 / 2 \mathrm{ft}$. high, $\$ 2.00$ each; $3 \mathrm{ft}$. high, $\$ 2.50$ each.

\section{CROTONS}

Very desirable on account of their highly colored foliage. Largely used in ornamental baskets at the holiday season. Strong plants, 4 -inch pots, $\$ 25.00$ per 100

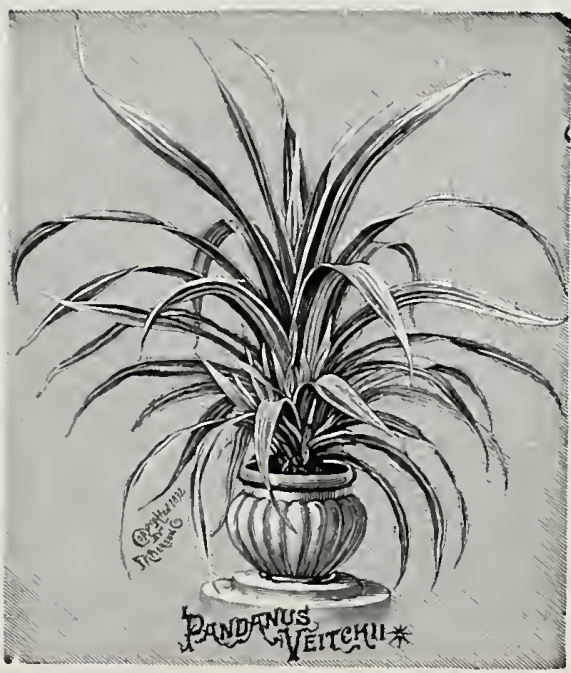

SMALL FERNS FOR FERN PANS A good assortment of the leading varieties for use in filling fern pans, - Aspidium, Cyrtomium, $21 / 4$-inch pots, $\$ 3.50$ per 100 .

\section{PANDANUS VEITCHII}

We have a fine stock of plants well colored. One of the finest of all our decorative greenhouse plants. Strong plants, 6-inch pots, $\$ 1.00$ each; 7 -inch, $\$ 1.50$ each.

\section{ASPARAGUS}

Plumosus nanus. $-2 \frac{1}{4}$-inch pots, $\$ 4.00$ per $\$ 8.00$ per 100 .

\section{CYRTOMIUM ROCHFORDIANUM (Crested Holly Fern)}

A most important addition to our list of ferns Foliage is a rich, deep, glossy green like Cyrtomiun falcatum, but the leaflets are deeply cut, or toothed, It makes a beautiful house plant, and is very popular. Strong plants froin 6 -inch pans, $\$ 6.00$ per dozen.

\section{KENTIA BELMOREANA}

Strong plants, 5 -inch pots, 18 inches high, 6 leaves, $\$ 9.00$ per dozen; 5 -incl pots, 26 to 28 inches high 6 to 7 leaves, $\$ 12.00$ per dozen.

\section{PHOENIX ROEBELENII}

One of the most graceful and beautiful of all palms. Very hardy. Fine large plants, 12-inch tubs, $\$ 5.00, \$ 7.50$ and $\$ 10.00$ each.

\section{ASPIDIUM TSUSSIMENSE}

One of the hardiest and most useful ferns for house culture. Fine plants for the centers of fern pans. Strong plants, $31 \%$-illch pots, $\$ 15.00$ per 100 .

\section{FICUS ELASTICA}

(Rubber Plant)

Strong plants, 6-inch pots, $\$ 6.00$ and $\$ 9.00$ per dozen

\section{BOXWOOD}

In new cypress tubs

Pyramids. $-31 / 2 \mathrm{ft}$. higl, $\$ 4.00$ each; $4 \mathrm{ft} ., \$ 5.00$ each; $41 / 2 \mathrm{ft}$. ,

Bush Boxwood. $-21 / 2 \mathrm{ft}$. high, $\$ 3.00$ each; $3 \mathrm{ft}$., $\$ 4.00$ each $31 / 2 \mathrm{ft}$., $\$ 6.00 \mathrm{each}$.

Ball or Globe Shaped. $-1 \frac{1}{2} \mathrm{ft}$. high, $\$ 5.00$ each; $1^{3 / 4} \mathrm{ft}$ $\$ 6.00$ each; $2 \mathrm{ft}$., $\$ 7.50$ each.

\section{ENGLISH IVY}

We have a fine stock of established plants grown in 4-inch pots, ready for immediate shipment. $\$ 10.00$ per 100 .

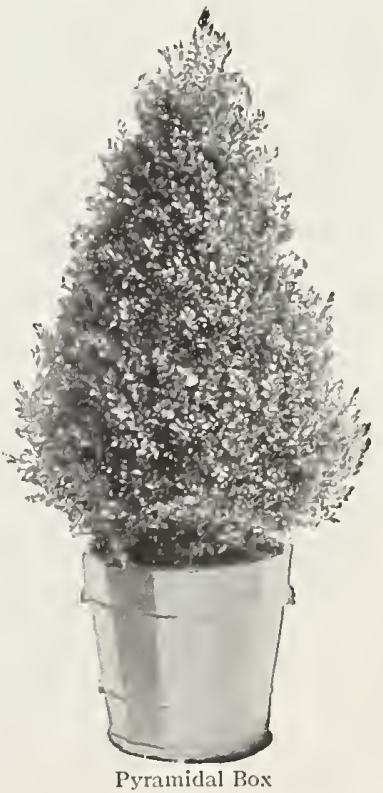




\section{NEPHROLEPIS ELEGANTISSIMA COMPACTA}

This dwarf, compact form of elegantıssima introduced by us in 1909, bears the same relation to that variety that Scottii does to Bostoniensis. The fronds are considerably shorter than those of elegantissima, and it throws a great many more crowns, making it a very bushy, compact, symmetrical plant. It has an ideal habit, and occupies a place by itself, being as distinct from elegantissima as that variety is from the original Piersoni. While it occasionally throws a few Boston fronds when growth is checked, its dwarf, compact habit makes it particularly desirable. It is especially valuable for growing in small-sized pots, making particularly fine, perfect specimens even in a 4-inch pot.

Plants from 21/4-inch pots, $\$ 6.00$ per $100 ; 3 \frac{1}{2}$-inch, $\$ 3.00$ per dozen; 6 -inch, $\$ 6.00$ per dozen; S-inch, \$12.00 per dozen.

\section{NEPHROLEPIS MAGNIFICA}

This is the daintiest of all the Nephrolepis. The fronds are very fine and filmy, on which account it has been called The Lace Fern. It is an improved variety and the best of this type. It makes a most beautiful plant, especially in the smaller sizes. Nothing is daintier or more exquisite than well-grown specimens in small pots up to 6 -inch. Very perfect little specimens can be grown even in $21 / 4$-inch pots. Fine for table decoration.

Plants from 31\%-inch pots, \$3.00 per dozen; 5-inch, \$6.00 per dozen.

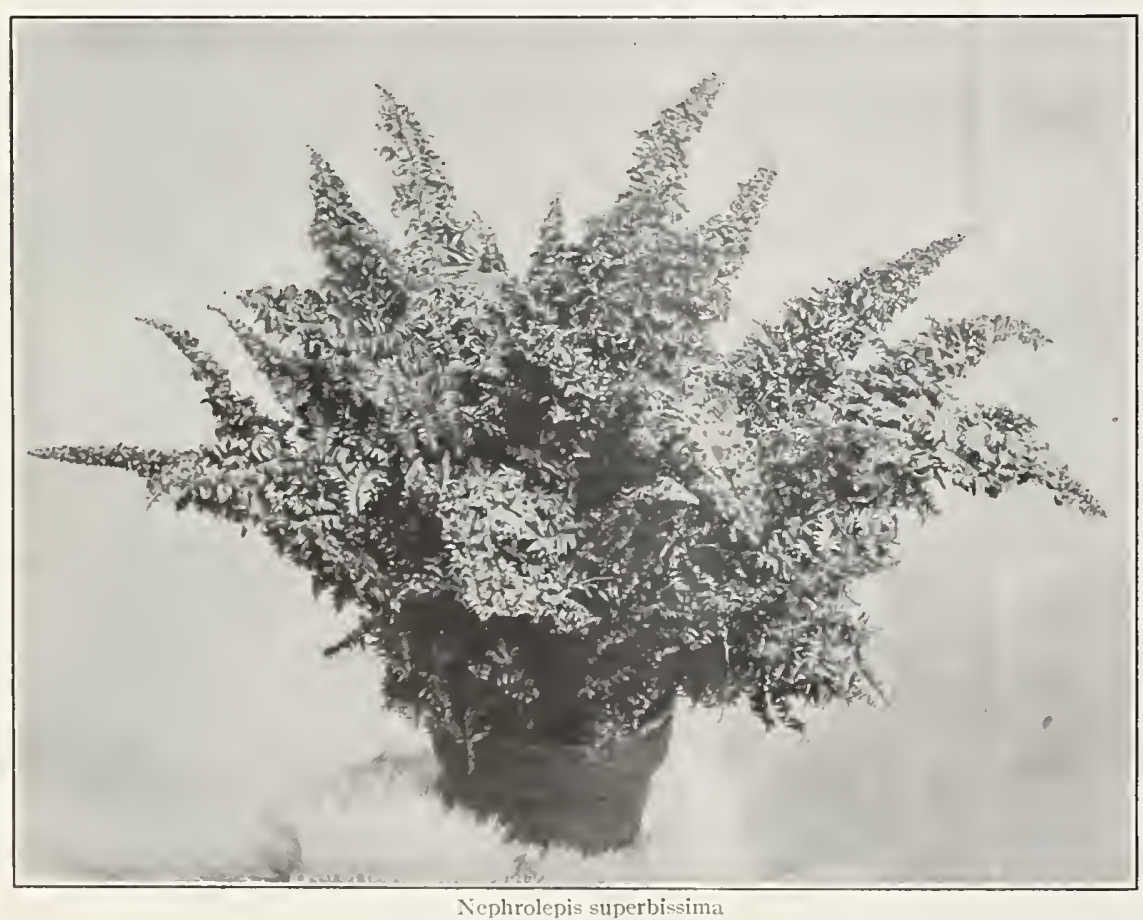

SMALL FERNS FOR FERN PANS

A good assortment of the leading varieties for use in filling fern pans,--Aspidium, Cyrtomium, Pteris in variety, Lastrea, etc. Strong plants from $21 / 1$-inch pots, $\$ 3.50$ per 100

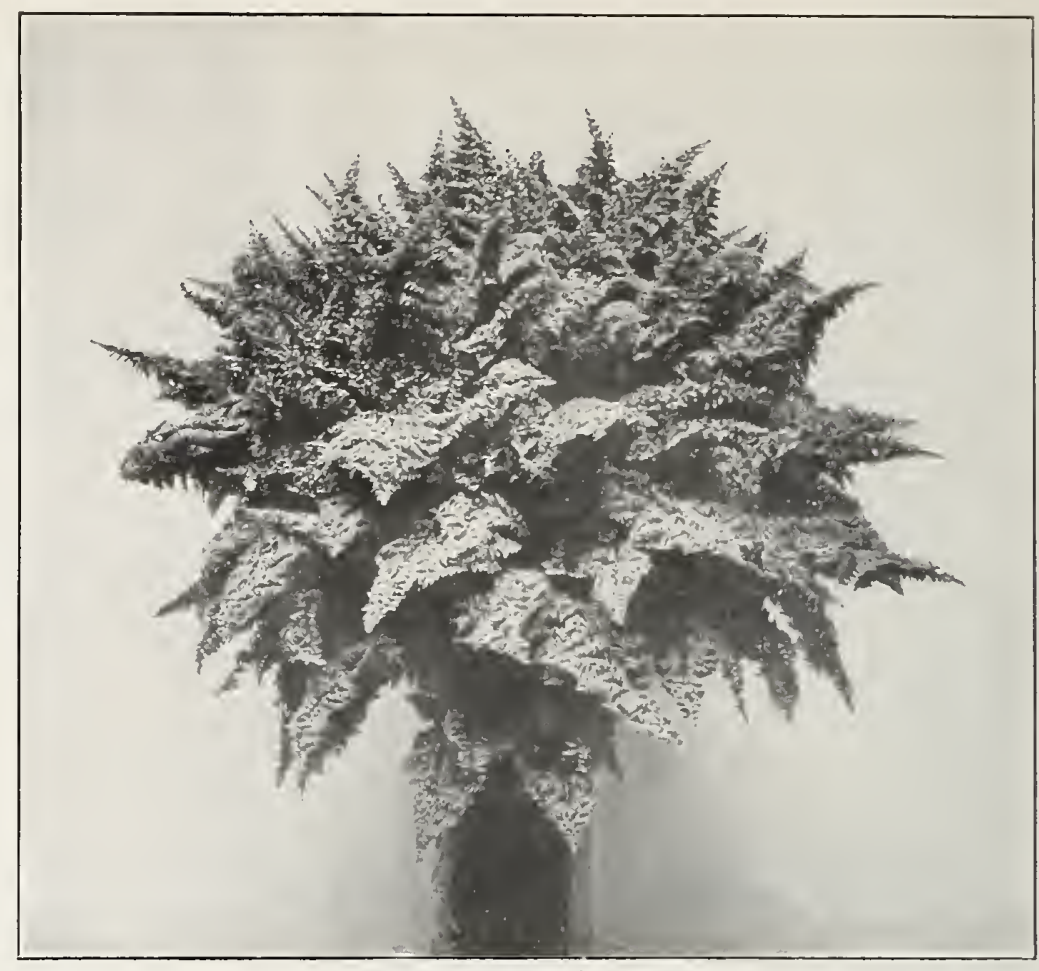

Nephrolepis elegantissima compact:

\section{NEPHROLEPIS SUPERBISSIMA}

I remarkable fern, originating with us and introduced in $190 \mathrm{~s}$. 1t is one of the most unique and distinct varieties ever introduced. lts distinguishing characteristics are it dense growth and dark green foliage. Fronds are very heavily imbricated, the pinnite overlapping, making the fronds very dense and compact. It has a very sturdy habit. and the fronds are very firm and rigicl. $1 \mathrm{t}$ is absolutely distinct, not only in formation of its fronds and color of foliage, but also in its habit of growth and general characteristic.. It is well named superbissima, as it is one of the most superb ferns. It was awarded a first-class certificate by the Royal Horticultural Society of London-its highest awardin 1908, the plants exhibited having been shipped from New York two weeks before that time. The same plants were then shipped to Edinburgh, Scotland, where they wore again awarded a certificate by the Scottish Horticultural Association. This indicates not alone the value of the plant, but also demonstrates in a very conclusive manner its fine keeping and shipping qualities.

Plants from 6 -inch pots, $\$ 6.00$ per dozen; S-inch, $\$ 12.00$ per dozen. 


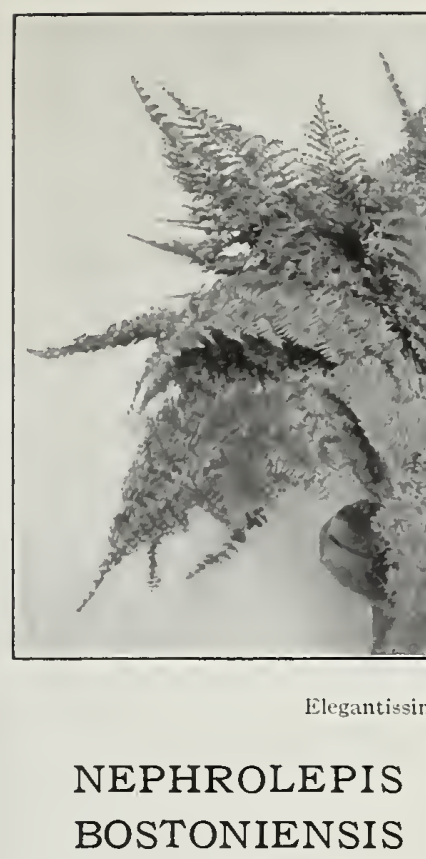

IVe always carry a fine stock of this variety, which is too well known to need any description.

Plants from 6-inch pots, $\$ 6.00$ per dozen; s-inch, $\$ 12.00$ per dozen.

\section{NEPHROLEPIS SCOTTII}

This has always been a favorite variety. It makes a very fine (warf, compact plant.

Plants from 6 -inch pots, $\$ 6.00$ per dozen

\section{NEPHROLEPIS PIERSONI ELEGANTISSIMA}

()f the many varieties of Nephrolepis, beginning with Piersoni, introduced by us in 190:3, we consider this new and improved form of elegantissima by far the most valuable of all. By selection, we have sucreeded in fixing a perfect form, which shows no tendency whaterer to revert to the original type, it never having thrown a single Boston frond in the eight years that we have grown it, for which reason it is much superior to the original elegantissima, Whitmani, Todeaoides, etc. Nany firms would have introduced this new and improved form under another name and at a high price, but we have a pride in perpetuating it under its original name. It outsells any other variety, and we have no hesitation in pronouncing it the most beautiful and most salable of all the varieties of Nephrolepis yet introduced.

Plants from $21 \frac{1}{4}$-inch pots, $\$ 6.00$ per $100 ; 6$-inch, $\$ 6.00$ per dozen; 8 -inch, $\$ 12.00$ per dozen; cxtril large specimens, 10 -inch, $\$ 3.00$ each; 12 -inch, $\$ 5.00$ each.

\section{NEPHROLEPIS \\ HARRISII}

This is a very superior and distinct type of Bostoniensis, being similar to that popular variety, except that the fronds are convoluted, or way, and, also, broader and more sharply pointed. The pinnae are beautifully fluted, making it very distinct and beautiful.

Plants from $21 / 4$-inch pots, $\$ 6.00$ per $100 ; 6$-inch, $\$ 6.00$ per dozen; S-inch, \$12.00 per dozen; 10-inch, $\$ 2.00$ to $\$ 3.00$ each; 12 -inch, $\$ 5.00$ each.

\section{NEPHROLEPIS MUSCOSA}

(The Moss Fern)

This new Nephrolepis, introduced by us in 1911, is a sport from superbissima, and has the same rich dark color, but the foliage is very fine and moss-like, which suggested the name, as this is the distinctive ("haracteristic of the plant. It makes a very beautiful, distinct, and refined plant, especially in the small size's, making most beautiful specimens in small pots. Its distinctiveness and beaty commend it to all plant lovers.

Plants from $31 / 2$-inch pots, $\$ 3.00$ per dozen; i)-inch, $\$ 6.00$ per dozen.

\section{SMALL FERNS FOR FERN PANS}

A good assortment of the leading varieties for use in filling fern pans, - Aspidium, Cyrtomium, Pteris in variety, Lastrea, etc. Strong plants from $2 \frac{1}{4}$-inch pots, $\$ 3.50$ per 100 . 

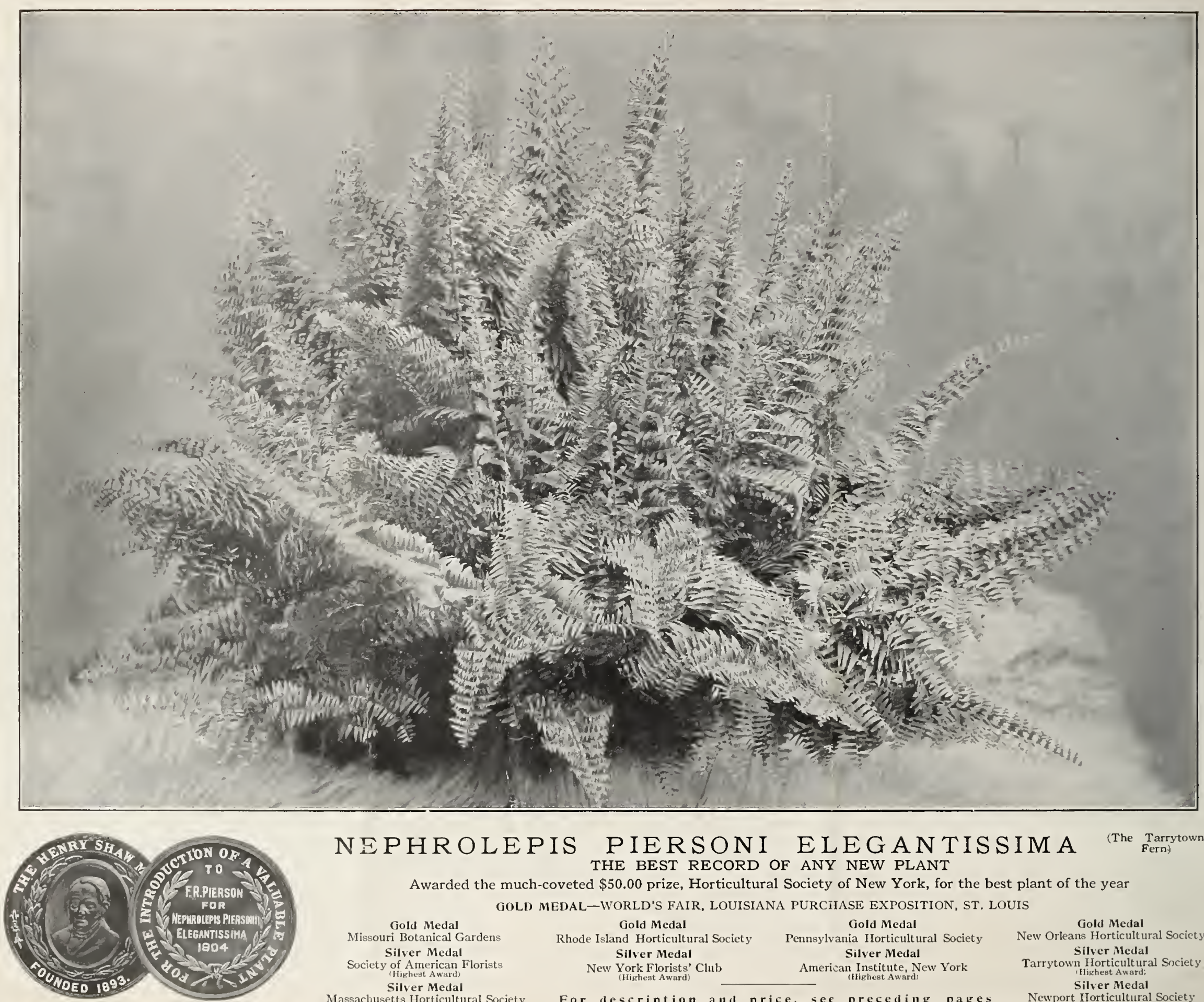

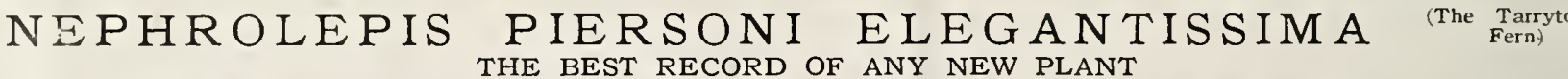

Awarded the much-coveted $\$ 50.00$ prize, Horticultural Society of New York, for the best plant of the year GOLD MEDAL-WORLD'S FAIR, LOUISIANA PURCIIASE EXPOSITION, ST. LOUIS

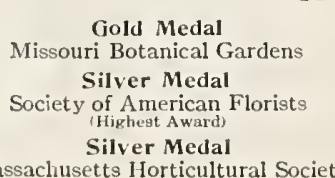

$\begin{array}{cc}\begin{array}{c}\text { Gold Medal } \\ \text { Rhode Island Horticultural Society } \\ \text { Silver Medal }\end{array} & \begin{array}{c}\text { Gold Medal } \\ \text { New York Florists' Club }\end{array} \\ \text { (Highest Award) } & \text { American Institute, New York } \\ \text { (Highest Award) }\end{array}$

Gold Medal
New Orleans Horticultural Socicty New Orleans Horticulturat
Silver Medal Tarrytown Horticultural Snciety Silver Medal
Newport IJorticultural Society

Silver Medal
Massachusetts Horticultural Society

For description and price, see preceding pages 